\title{
REVISITING THE BACHELORHOOD OF BASIL II ${ }^{1}$
}

\author{
Mark Masterson
}

'[Emperor] Basil [II] was unmarried and notoriously celibate.'

(Stephenson 2003: 61)

'He [Bardas Skleros] did not offer military counsel but gave cunning advice instead ... [a point in this advice was the following:] don't bring a wife into the palace...'

(Michael Psellos, Chronographia 1.28)²

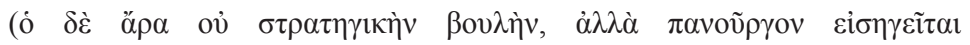

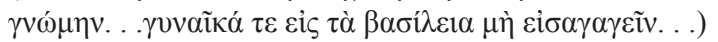

'Il est possible que, en dépit de tout son zèle normatif pour prohiber les actes homosexuels, la société byzantine les ait en fait tolérés tant qu'ils ne faisaient pas scandale.'

(Laiou 1992: 78)

Basil II was the most accomplished emperor of the Macedonian dynasty. Emblem of Byzantine success in the Middle Ages, he receives glowing press in historical accounts. Military triumph and consolidation of imperial power are hallmarks of a lengthy reign, effectively as sole emperor, ${ }^{3}$ that stretched from 976 to 1025. Probably born in 958, he was associated with his father Romanos II as emperor from an early age. When Romanos died in 963, he was subordinate first to his mother Theophano, who was regent (963), then to emperor Nikephoros II Phokas (963-969), and finally to emperor John I Tzimiskes (969-976). And even after Tzimiskes was no longer on the throne, all authority was not his: unofficially, but in a real way, he shared the rule with his powerful great-uncle, the eunuch Basil the parakoimomenos, until the mid-980s. ${ }^{4}$ Among his accomplishments, once he was sole emperor, were the bloody suppression of the Bulgarian state, significant land legislation against the interests of the major families, and a bulging treasury by the end of his reign. ${ }^{5}$ Basil also faced significant revolts early on: those of Bardas Skleros (976-979 and 987-989) and Bardas Phokas (987-989). Great-great-grandson of 
Basil I, Basil II traced his Macedonian lineage down from him through Leo VI and Constantine VII Porphyrogennetos, to his father, Romanos II. He also counted another emperor, Romanos I Lekapenos, as a great-grandfather. Lineage and marriage were important in this dynasty and in Byzantine society as a whole. Basil had been betrothed along with his brother, Constantine, to Bulgarian princesses when he was young. ${ }^{6}$ Given the importance of lineage which will keep members of the dynasty on the throne in the eleventh century well past Basil's death, it is remarkable that he did not take a wife at some point over the course of his reign. Holmes has called him an 'elusive figure'. 'His bachelorhood is the most elusive thing about him.

This chapter will discuss the fact that Basil did not wed. The goal is to rebalance the scholarship on this question, as discussion of his unmarried state has been problematic, and frequently obfuscatory. Taking Michael Psellos' portrait of Basil as a generally grim man as a starting point, scholarly accounts have often explained his demurral to wed by making him a monk manqué whose asceticism has a vague religious basis. At other times, it is considered possible that he wished to avoid meddling in-laws. While Psellos reports that Basil did affect a spare demeanor and we can imagine that the prospect of a wife's relatives might have given him pause, these things do not conclusively answer the question of why he remained a bachelor. Arguments to come will explore the possibility that the enigmatic and never married Basil was perceived to be, at least at times, interested in same-sex sexual encounters.

A parable from Symeon the New Theologian's Oratio Ethica 10, in which an emperor takes a rebel to bed, makes a strong, though suggestive statement about same-sex sexual desires in Basil II. Seen in relation to evolving attitudes toward same-sex sexual behaviour between men in Byzantium, the political situation in Basil's reign, Symeon's position as an ecclesiastical leader both apart from the secular world and in it, and the depiction of emperor and his court in Symeon's writings, this work from the early 1000s gives evidence for a stream of thought about the bachelorhood of the current emperor. Symeon's text strongly suggests that some of Basil's compatriots felt comfortable attributing same-sex desire to their emperor. Indeed, while we cannot know the truth - Basil, invisibly to history, could have been visiting female prostitutes, for example - a narrative of interest in same-sex encounters is better supported than one of sexuality refused altogether, or, needless to say, one of desire for women alone. The ultimate conclusion is this: the question of Basil's bachelorhood should remain an open one; he did not marry for reasons that are hard to make out, and it is quite possible that same-sex desires were a contributing factor in his decision.

\section{The state of the question of Basil's bachelorhood}

Most of the time, scholars explain the bachelorhood of Basil with evidence from Psellos and, at times, Ademarus Cabannensis (Adémar de Chabannes). Psellos provides a grim and ascetic demeanor and Ademarus a vow that Basil supposedly 
made to become a monk. Asceticism and (sometimes) a vow thus explain imperial bachelorhood. Concern about in-laws sometimes supplements this explanation, or is offered by itself, about which, more below. But the question of his bachelorhood is not as settled as it sometimes is implied, or is said to be. ${ }^{8}$ But first, as I aim to trouble the combination of Psellos and Ademarus as a basis for approaching Basil's bachelorhood, we need to consider the evidence of these two authors and its use by scholars.

Psellos' portrait of Basil in Book One of the Chronographia is an overwhelming presence in scholarly commentary on Basil's unmarried state. Of particular importance is the austere manner Psellos says Basil assumed after he put down the revolts of Bardas Skleros and Bardas Phokas. Psellos says that he was different prior to the revolts; he 'used to feast openly and frequently made love $(\theta \alpha \mu \grave{\alpha}$

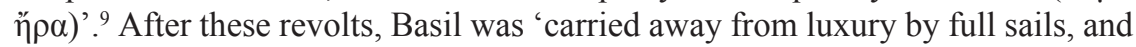
he held himself to endeavor with all his soul', ${ }^{10}$ and once Bardas Phokas' head had been presented to him, ${ }^{11}$

the emperor became someone else, and the changed state of affairs was gladdening him no more than had the terror of events vexed him. Subsequently, he was seen to be suspicious of all, haughty in his bearing, hiding his thoughts, quick to anger and heavy in his wrath with those who made mistakes. ${ }^{12}$

This grim affect was correlated by sober dress, ${ }^{13}$ possible asceticism,,${ }^{14}$ and a court that was, in Psellos' opinion, insufficiently brilliant. ${ }^{15}$ It is probable, too, that Psellos addresses Basil's unmarried state in the advice he says Bardas Skleros gave him, when Basil and he met after his second revolt ended:

He [Bardas Skleros] did not offer military counsel but gave cunning advice instead ... [a point in this advice was the following:] don't bring

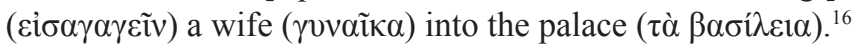

While there is scope in how one reads eisagagein, gynaika, and ta basileia, the most natural interpretation of this passage is that Bardas is telling Basil not to marry. ${ }^{17}$

In recent decades, scholars have shown awareness of the constructed nature of Psellos' account and of complexities in it that militate against viewing his Basil as only dour. ${ }^{18}$ Barbara Crostini has underscored how Psellos speaks to his eleventh-century audience about an imperial court proper to the empire and Basil's provides an example not to be followed. Psellos' narrative is tendentious at times, for, as Crostini has pointed out, a number of Basil's associates were estimable intellects ${ }^{19}$ and cultivated letters from them have survived. ${ }^{20}$ Lynda Garland notes that Psellos has often been read in ways that are reductive of the complexity of his portrait of Basil: not grim all the time, he joked. ${ }^{21}$ Crostini counsels that Psellos is not that reliable and Garland suggests that he 
be read with greater care. Taking a different tack, Catherine Holmes calls less and more directly for decreased reliance on Psellos to understand Basil's reign. ${ }^{22}$ She has presented a case for putting John Skylitzes' Synopsis of Histories into a commanding position. ${ }^{23}$ She also offers nuanced understandings of the varied relationships Basil had with the leading families in the empire and the essential role the military played in the maintenance of his power. ${ }^{24}$

Still, though, this nuancing of Psellos and salutary addition of Skylitzes has had no effect on understandings of Basil's bachelorhood. One reason for this is the fact that neither Psellos nor Skylitzes discusses it, though, as noted above, Psellos at least mentions it when he speaks of not bringing a wife into the palace. In any case, when addressing his demurral to wed, scholars to a person do not see samesex desire as a possible driver in Basil's unmarried state. The Chronographia's proffered grim affect leading into asceticism ${ }^{25}$ sets most of the agenda, along with occasional speculation that he did not want troublesome in-laws. Basil did not marry because he had embraced 'an ascetic way of life early in his reign' ${ }^{26} \mathrm{He}$, now 'cruel and austere' after 989 and '[having spent] his bachelorhood in various

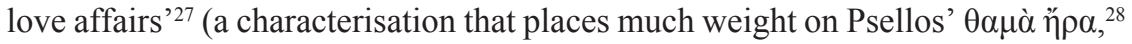
and indeed, assumes much about both the Greek verb and the matter at hand), did not take a wife because he wanted 'to avoid meddling by a wife or her relatives' ${ }^{29}$ Shaun Tougher does not think 'sexual preference' was at issue and finds it 'likely that his decision [not to wed] was taken on religious grounds' ${ }^{30}$ Still others think there was a religious vow. ${ }^{31}$ Religiously motivated asceticism is possible, but the vow, as Crostini pointed out, is not supported by Psellos' text. ${ }^{32}$ Indeed, Psellos never connects Basil's moods and affect to his bachelorhood and bachelorhood is addressed only by Bardas Skleros in his advice. ${ }^{33}$

The reader will note the idea of a vow confirming Basil in his bachelorhood is not found in Psellos. This vow that leads Basil full sail away from marriage is found in another text, the Chronicon of Ademarus Cabannensis. This work, penned in France in the early years of the eleventh century, ${ }^{34}$ is the highly unreliable centrepiece of Martin Arbagi's 1975 article 'The celibacy of Basil II'. This article, which is cited often and even recently, ${ }^{35}$ is problematic and should no longer be the go-to on the subject of Basil's celibacy. What makes the prize piece of evidence, Ademarus' Chronicon, so unreliable?

In the third book of the Chronicon (a work concerned mostly with the history of France and the Franks), Ademarus relates how Basil swore to become a monk if he defeated the Bulgarians. Ademarus' narrative in general has problems, chief among them mistakes about what happened during Basil's lengthy conflict with the Bulgarians. ${ }^{36}$ But Ademarus' handling of the chronology of the vow and its fulfilment particularly diminishes his persuasiveness as a source on Basil:

[E]nraged at them (sc. the Bulgarians), emperor Basil bound himself with a vow to God that he would become a monk, if he could subdue the Bulgarian people for the Greeks... [and once success was 
achieved] ... just as he had promised with his vow, he assumed the monastic way of life in the Greek style for the rest of his life [from 1018 going forward; through perhaps from 1014], abstaining from sexual pleasure and meat, while he was surrounded on the outside by imperial regalia. ${ }^{37}$

With defeat of the Bulgarians achieved once and for all in 1018, though it is possible to regard the vow as acted on in 1014 with the Bulgarians' disastrous defeat at the Battle of Kleidion (an important event not mentioned in Ademarus' account), this means that Basil finally keeps his promise to God when he is around sixty years old (1018), or perhaps around his fifty-sixth birthday (1014). So, according to Ademarus, Basil's determination to bring the dangerous Bulgarian state to heel was the reason for his bachelorhood. But a vow to become a monk fulfilled so late in life, while providing an answer, raises questions: what, for example, happened in the years before? In any case, Arbagi finds Ademarus useful because his depiction of Basil's character is 'uncannily accurate', by which he means it corroborates what Psellos says. ${ }^{38}$ This then means that we should believe other things, including the vow.

In an article concerned with Ademarus himself that takes the position that Basil did not make a vow but was just inclined to asceticism, ${ }^{39}$ R.L. Wolff discusses Ademarus' tastes for forgery and delusion which are relevant here. In addition to his demonstrable ignorance of the realities of Basil's reign, Ademarus shows himself to be untrustworthy in general: he tried his utmost to make St. Martial the thirteenth apostle, even forging documents to bolster his case. ${ }^{40}$ In any case, to the extent that Wolff speaks of Basil's asceticism, he replicates a simplified version of Psellos' viewpoint. Wolff also vaporises Ademarus as testimony to Basil's bachelorhood, and we, now having no vow, lean hard on Psellos' characterisation of Basil's grim sense of purpose in performing his duties and a suite of mostly unmotivated actions in Ademarus.

In considering the general effect of scholarship that uses Psellos and Ademarus, sometimes via Arbagi and sometimes not, to understand Basil's character and bachelorhood, we will note that Psellos is used to validate Ademarus who only, we are to believe, exaggerated things. The question of Basil's celibacy, which is of great interest from the standpoint of gender studies and should attract careful attention because of its nearly unprecedented nature, ${ }^{41}$ is not well explained by reductive reading, on the one hand, of one source that advertises its literary constructedness, and, on the other hand, by use of a source from an author known to be mendacious and who clearly has only the vaguest idea of what was going on in the Byzantine empire.

While it cannot be said for sure why this yoking of cultivated Byzantine man of letters with shifty Frankish chronicler has not received the hard questioning it deserves, it seems to me anxiety about possible sexual 'irregularity' in the great military emperor has disabled critical faculties. Leaving Basil unmarried amid his exceedingly homosocial court, into which no wife was 


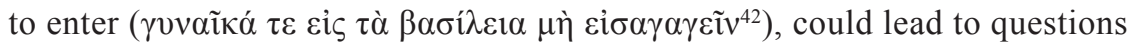
about same-sex desire. And so unconscious or not so unconscious nervousness among scholars about same-sex desire and sexual relations has kept this unlikely team yoked and pulling the wagon, as it were, of Basil's bachelorhood (when the question has been broached at all). But we need not remain in this unsatisfactory place. There is other evidence, probably ignored because of reasons just stated and because of its metaphorical nature, which is contemporary and situated in Basil's milieu: a parable from Symeon the New Theologian's Oratio Ethica 10.

\section{Symeon's evidence}

Symeon the New Theologian was a monk, hegoumenos of a monastery, possessor of an oratory, and important ecclesiastical writer who was a little older than Basil and a eunuch. ${ }^{43}$ His dates were probably 949-1022. Before becoming a monk he held a position, spatharokoubikoularios, in the imperial court. ${ }^{44}$ If, as seems likely, Catecheses features a moment of autobiography, ${ }^{45}$ Symeon was well informed about the ways and means of exciting same-sex desire at this point of his life, ${ }^{46}$ though he later embraced virtue. He probably wrote the tenth Oratio Ethica, as part of a set of fifteen orations, during the first decade of the 1000 s, which was a time when he was at odds with Basil and the imperial government. Darrouzès thought the tenth oration and the others in the collection bear the marks of struggle. ${ }^{47}$ In this difficult decade, he lost control of the St. Mamas monastery in Constantinople, ${ }^{48}$ after having been tried for fostering allegedly improper reverence for his recently deceased mentor, Symeon Eulabes. ${ }^{49}$ In the middle of the decade he was also tried for heresy, ${ }^{50}$ and at the decade's end he went into exile across the Bosporus to Chrysopolis. ${ }^{51}$ There, one of Symeon's lay supporters, Christopher Phagoura, bought him an oratory dedicated to St. Marina at Paloukiton. ${ }^{52}$ He resided there until his death. ${ }^{53}$

The tenth Oratio Ethica contains a parable of an emperor who forgives a rebel. This parable is drenched in same-sex eroticism. Arguments to come will suggest that a Byzantine audience would have had reason to think of Basil when hearing/ reading the parable and that Symeon could have wanted this. ${ }^{54}$ First, though, what is this oration and its parable?

The prevailing theme of Symeon's tenth Oratio Ethica, called On the Fearful

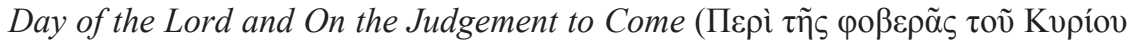

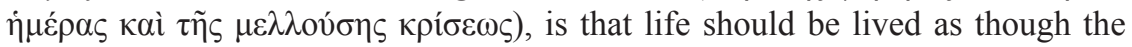
Final Judgement were already present. Living this way is not hard to do. ${ }^{55}$ The light speaks in the here and now. ${ }^{56}$ Living in accordance with God's commandments is to have it as easy as a rebel does in a parable Symeon offers as an illustrative example (10.234: paradeigma/ $\pi \alpha \rho \alpha \delta \varepsilon \tilde{i} \gamma \mu \alpha)$. In this lengthy parable, ${ }^{57}$ Symeon tells the story of a rebel who was in the service of an opponent of the emperor of the Christians. ${ }^{58}$ The emperor tries to persuade the rebel to defect and, rewarded, join him on the throne: 
He was given secret messages through various means by the emperor of the Christians that he should come to him, be with him, receive great gifts, and rule with him. ${ }^{59}$

This man initially is not persuaded and even redoubles his hostility. ${ }^{60}$ Ultimately, he surrenders, showing much stagey regret: 'Going to the emperor and embracing his feet, he begged with wailing for pardon ${ }^{6}{ }^{61}$ The emperor accepts, and his acceptance is quite demonstrative:

'[The emperor] fell upon his neck and kissed him' ${ }^{62}$ all over and [kissed too] those eyes of him [i.e., the rebel] which were shedding tears for many hours. Then, having ordered that a crown, robe, and shoes similar to those he was wearing be brought, he himself personally clothed his erstwhile enemy and opponent, in all ways avoiding any verbal abuse of him. And not only this, but as he was rejoicing in him all day and all night, holding him tight, embracing him lovingly, mouth to mouth, to so great extent did he 'over-love' him that he did not separate himself from him in sleep, lying down with him, holding him tight on the bed, covering him completely with his paludamentum ${ }^{63}$ and putting his face on all his members. ${ }^{64}$

This is certainly erotic and carnal. Over the years it has struck some readers as excessive ${ }^{65}$ Symeon signals that it is excessive by saying that the emperor did not merely love the rebel, he 'over-loved' (i் $\varepsilon \varepsilon \eta \gamma \alpha \dot{\pi} \pi \eta \sigma \varepsilon v$ ) him. This verb with its prepositional prefix hyper/vंté pushes the reader or listener to the conclusion that something is too much. Hyper is an invitation to interpretation. The question we will consider here is what the possible semantics of this excess are.

A first approach to this 'excessive' carnal content might regard the sheer inappropriateness of the imagery as a fitting depiction of the singularity that is the fearful day of Final Judgement. As the Final Judgement is the end of all things, there is nothing to which it is comparable. The worldly ways and means of sex between men hardly fit this incomparable celestial event. The metaphor stages the inevitable failure of representation and the event's incomparability. The passage as a whole is ironic and gestural on this reading.

A second approach to the 'excessive' carnal content might think in terms of the continuities things of this world have with things celestial. Seeing the parable in relation to Symeon's frequent embrace of the corporeal, Derek Krueger 'argue[s] that Symeon employs same-sex desires in order to emphasize the male monastic body as a locus of theōsis, the deification of humanity'. ${ }^{66}$ Indeed, Symeon's embrace of the bodily leads him, in the context of making a point about the Incarnation, to say that even as his finger is Christ, so also is his penis (balanos). ${ }^{67}$ And so this passage speaks to the nature of the Incarnation ${ }^{68}$ and only 'over-love', 
the word and not the entire passage, is the locus of an irony. Another way to put this is that hyper brings to a reader's or listener's notice the understanding of someone who is sceptical about the nature of the Incarnation and connections between this world and the next.

But there is more to note. 'Over-love', advertising excess as it does, counsels the listener/reader to think about how this instance of forgiveness has discontinuities with other portrayals of forgiveness. This is emphatically a direction to go in, for there is a portrayal ready to hand. Symeon quotes Luke 15:20, a text that all in his audience would have known. The carnal approach to forgiveness on display in Symeon's parable far outpaces Luke (from the tale of the prodigal son):

While he [the prodigal son] was still keeping himself a fair ways away, his father saw him. He felt compassion, and, running, he fell upon his neck and kissed him. ${ }^{69}$

The demonstrativeness in Luke is chaster: none of the togetherness day and night, covering paludamentum, or face on all the members. The parable, therefore, is no moment of scriptural exegesis but a registering of distance, and the emperor's distance from the paradigm offered by the New Testament is an implicit criticism of the emperor.

Luke is not the only text that can underscore via comparison the parable's excessiveness, the semantics of which again is disapproval. The fact that Symeon was also the currently embattled, or recently dispossessed, leader of the monastery of St. Mamas could have called to mind another scene of imperial forgiveness: that by emperor Maurice (582-602). The monastery of St. Mamas was founded by Maurice, ${ }^{70}$ and this emperor features in a parable concerning him and a bandit in Anastasius of Sinai's oration (c. 700) on Psalm Six. ${ }^{71}$ In this parable of imperial forgiveness, Anastasius relates how an archbandit (archileistes), who had been laying waste to Thrace, was made good through the forgiving excellence of the emperor. The bandit meets Maurice, and like a sheep falls to the emperor's feet, embraces them, and begs forgiveness. Maurice grants it. The bandit falls mortally ill shortly thereafter. While the bandit was breathing his last, his doctor saw a vision of the weighing of the sins of the archileistes. Things do not look good for the bandit, whose misdeeds are weighty. But two angels discover the bandit's tears on his tunic and these outweigh the sins. Awakening from his dream, the doctor rushes to find the body of the archileistes still warm. The doctor then tells the emperor everything, remarking that the bandit helped himself through his confessions to authorities celestial and terrestrial:

I have heard that the bandit was saved through confession to the cross of the heavenly emperor, and I know that the bandit was [also] saved through confession to your imperiality ( $\left.\dot{\varepsilon} \pi \mathrm{i} \tau \tilde{\eta} \varsigma \sigma \tilde{\eta} \varsigma \beta \alpha \sigma \iota \lambda \varepsilon^{\prime} \alpha_{\varsigma}\right){ }^{72}$ 
In comparison, Symeon's emperor of the Christians (which is what Anastasius calls Maurice too: $P G$ 89: 1112A) is excessive and, as in the case of comparison with the scene in Luke, surely 'over-loving' if the reader has Maurice in mind; an embrace of his feet is the extent of bodily contact with the bandit. Nor does Maurice put the bandit in a position of authority or dress him in imperial raiment. Symeon's over-loving emperor shows excess at the level of the body (bed) and excess in giving up authority (this man becomes co-emperor). Luke says that Symeon's emperor's behaviour falls short of the New Testament, and memory of Maurice's archileistes makes the parable legible as commentary on the current holder of the throne, Basil II. This homoerotic behaviour, excessive, is quite the semantic vehicle. But how serious a thing would this be to attribute to Basil? On the basis of other moments in Symeon's works, civic and canon law, and a contemporary saint's life, it will be argued presently that same-sex sexual behaviour was a carnal temptation and not the serious business it was for a time in earlier centuries or would be in early-modern and later western Europe. Implying that Basil, obstinately unmarried, had tastes in the direction of other men, was not as serious as some now might imagine.

\section{The weight of homoeroticism in medieval Byzantium}

The parable is not the only place in his works where Symeon speaks of desire and sex between men. ${ }^{73}$ In Hymn 24, amid continually asserting that since all are sinners, sin need not be a barrier to eventual communion with Christ, Symeon admits to being a sodomite: 'I became, alas, an adulterer in my heart and a sodomite in reality and by disposition' ${ }^{74}$ Later he gives the impression that he, when young and handsome ( $\left.\kappa \alpha \theta^{\prime} \omega \omega^{\prime} \alpha v\right)$, was sexually penetrated:

How was I able to bear in silence those things happening during my desirable young manhood, and, O my God, those things being done in wretched me? ${ }^{75}$

This hymn also features confession of many sins. He admits, for example, to being a male prostitute, a magician, and a pederast, all in line seventy-six. ${ }^{76}$ The scale of misbehaviour poses the question whether some of his admissions are less than real and are, instead, rhetorical didactic. ${ }^{77}$ Adjudication of the question of rhetoric versus reality postpones a necessary discussion, though, for a different question, 'Why this didactic rhetoric?', is one that demands a hearing. For Symeon says, to the discomfort of some scholars, ${ }^{78}$ that adultery was merely aspirational, and that sodomy, suited to his desires, happened

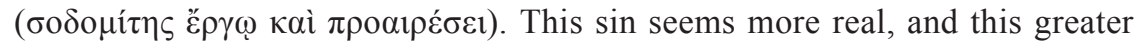
degree of reality shows this desire to be less remarkable within Symeon's milieu than we might imagine now. In any case, the words that introduce the parable of rebel and emperor cast the coming corporeality as but an image Symeon had to hand: 
Our master and God has commanded nothing severe, nothing burdensome, but, instead, things, all of them, easy and simple, just as - believe me - I myself know the command of God and the obtaining of him and his kingdom to be a simple thing. But I will show you this through an example. . . ${ }^{79}$

After finishing the parable, Symeon brings home its offhand nature in words that soon follow. Getting right with God is approaching him without pretension and running naked:

Therefore, my beloved brothers, leaving everything behind, let us run naked and, coming to Christ, our master, let us fall down and wail in the face of his goodness, so that he, having seen our faith and humility, in similar fashion and even to a greater degree, may receive us, hold us in honour, and bestow on us his robe and diadem, and make us guests worthy of the celestial bridal chamber. ${ }^{80}$

Being right with God is as easy and true as corporeal intimacy; this pleasure functions as a vivid and effective metaphor. While Symeon's move is hardly unprecedented - the carnal had often provided metaphors since Plato - the reader of the tenth Oratio Ethica and other works of Symeon has learned about the "erotic imaginary available to a middle-Byzantine monastic theologian" ${ }^{81}$ and about 'sexuality' in monastic settings in the late tenth to early eleventh centuries. The student of medieval Byzantium does well to remember Symeon's admission of same-sex sexual acts and the ease with which they pass into usable metaphor. A conclusion to draw is that this desire, at least in the time of Symeon and Basil II, was not productive of shame that disabled speech. Indeed, relative ease with same-sex desire is to be found outside of Symeon's writings.

In an important work from 1992, Angeliki Laiou remarks that same-sex sexual behaviour in Byzantium, which was forbidden in civil law, seemingly was not worth attention unless it caused a scandal:

Il est possible que, en dépit de tout son zèle normatif pour prohiber les actes homosexuels, la société byzantine les ait en fait tolérés tant qu'ils ne faisaient pas scandale. ${ }^{82}$

This revolutionary statement, while not unheralded and occasionally followed up, ${ }^{83}$ has not affected the study of Byzantine sexuality as much as it should have. There is evidence that this is the correct attitude to take. Scandalous sexual impropriety between men does not appear in the historical record of the middle Byzantine period. Regulations in civil law, mandating execution for sexual acts between males (although allowances were made for young offenders), appear to have been unused ${ }^{84}$ Furthermore, it has been suggested, and the historical record with its lack of executions is persuasive, that the laws were just copied. ${ }^{85}$ Observation 
of the sequence of laws from the eighth century into the tenth supports this idea. Ekloge 17.38 (AD 741), ${ }^{86}$ Eklogadion 17.6 (early ninth century), ${ }^{87}$ Epanagoge 40.66 (AD 886), ${ }^{88}$ and Prokheiros 39.73 (AD 907) ( $^{89}$ are terse, all four of them, and they repeat one another with but small variations. ${ }^{90}$

In contrast to civil law, regulations of a more liberal kind developed around same-sex behaviour in canon law. The fourth century had seen rigorous disapproval of same-sex relations in the penitentials. Basil of Caesarea's Canon Sixty-Two ${ }^{91}$ recommended fifteen years of excommunication and Gregory of Nyssa's Canon Four ${ }^{92}$ eighteen for same-sex relations between men, referred to

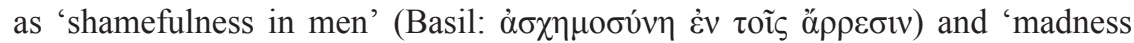

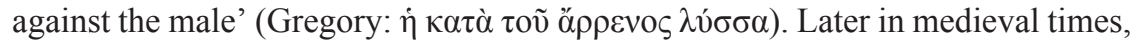
the rigor of the Cappadocian Fathers is left behind. Theodore the Studite (eighth to ninth centuries) recommends in his Canon Twenty only two years' excommunication, ${ }^{93}$ if it is clear that the man will no longer be engaging in 'shamefulness in men' ${ }^{94}$ Men who pay no mind to this canon are to serve the entire fifteen years Basil recommends, however. ${ }^{95}$ In the ninth or tenth centuries, in a collection that has been (incorrectly) attributed to John the Faster (aka patriarch John IV, 582-595), ${ }^{96}$ we again see shorter penances. ${ }^{97}$ Canon Eighteen specifies three years instead of Nyssa's eighteen or Basil's fifteen for 'madness for the male' ( $\alpha \rho \rho \varepsilon v \mu \alpha v i ́ \alpha$ ), and, as in the case of Theodore the Studite's recommendations, the unrepentant can serve Basil's fifteen years. ${ }^{98}$ In another canon, sex against nature between men (and the reference is to anal penetration: عi $\zeta$ ö $v \delta \rho \alpha \pi \varepsilon \sigma o ́ v \tau \varepsilon \varsigma$ ) draws two years of penance for those who did it only 'once, twice or three times'

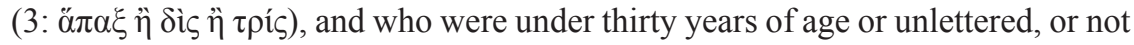
in possession of a wife. ${ }^{99}$ Still another canon specifies three years for those who are older and who may be guilty of 'doing this only once, twice or three times' (8:

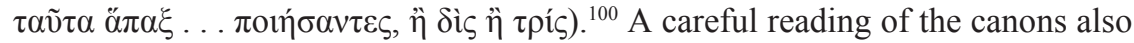
yields the conclusion that anal sex with another man was less serious than anal sex with one's own wife: the mildest penance for this was five years and could go as high as ten. ${ }^{101}$

The level of detail in these penitentials is also notable. Mutual masturbation between men is mentioned in one, ${ }^{102}$ and another features a discussion of anal sex

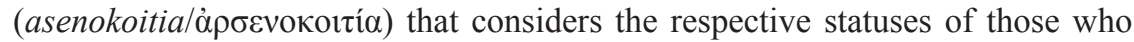
receive, those who give, and those who like both:

Concerning arsenokoitia. Arsenokoitia has three different kinds. One is to take it from another. This is less serious, whether on account of being under age, or poverty, or rape, or other various reasons. Another is giving it, and this is more serious than taking it. Then there is taking it from someone else and giving it to another. This defies any explanation. ${ }^{103}$

Even though what we call versatility among gay males today causes an aporetic reaction, it is worth noting that switching positions is a recognised possibility. The take-away, furthermore, is the evident ease about discussing same-sex sexual 
relations that one will not find, say, in early-modern western Europe, or earlier among the Cappadocian Fathers. We are not dealing with a situation where desire cannot speak its name: routes to carnal satisfaction are known and discussed. Same-sex sexual acts between men are temptations of the flesh and, as such, are to be avoided, but commission of mutual masturbation or arsenokoitia is not an unspeakable failing. Indeed, Symeon's ease in confessing his interest in same-sex sexual behaviour needs to be seen in the context of this (perhaps surprising ${ }^{104}$ ) liberalising dynamic.

A look at another ecclesiastical text further supports the idea that the Byzantine empire at the time of Basil and Symeon had a degree of relaxation and frankness around same-sex relations between men. In the anonymous Life of Maria the Younger from either the tenth or eleventh century, ${ }^{105}$ the narrative turns to one of the sons of Maria, Baanes. ${ }^{106}$ Though married, the soldier Baanes, beloved by the other soldiers, ${ }^{107}$ was particularly close to Theodore. He was 'yoked' to this man and the description of their life together features an excess of corporeality that recalls Symeon's parable, though it is curiously both more metaphorical and more graphic at the same time:

[Baanes] had a certain Theodore as fellow ascetic and helper in all his excellent exploits ... a man brave and strong in military matters but braver still in conducting his life for God. Yoked ( $\sigma 0 \zeta \varepsilon v \chi \theta \varepsilon i ́ \varsigma)$ to him, like a bull of good lineage and strong, they were ploughing in one another

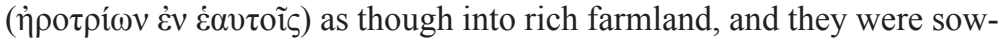
ing the seeds of excellences, as though the best of farmers. At the right moment, they cheerfully harvested. They laid up for themselves fruits beautiful to God in divine vats and got for themselves joy forever. ${ }^{108}$

The word, 'yoked' ( $\sigma 0 \zeta \varepsilon v \chi \theta \varepsilon i ́)$ ), is often used to refer to married couples and it is difficult to suppress thoughts of anal sex as they plough in one another. Corporeal expression of closeness is something that happens, it would appear, and it functions as a metaphor for something else (like Symeon's parable). And the writer does not make it easy for thoughts of anal sex to be left behind, if that is what a reader might like to do. At the beginning of the next section, less than one hundred words away, the reader discovers that Baanes' final illness was a diseased bowel. ${ }^{109}$ Furthermore, this relationship between Baanes and Theodore was not sui generis. Their closeness is prefigured by the relationship that Maria's husband Nikephoros had with a certain Bardas Bratzes.

Bardas was married to Maria's sister and he suggested to his dear friend Nikephoros that he marry Maria. A marriage connection would bring them closer together:

'Since,' he says, 'O dearest of men to me, we have become deeply involved with each other and are bound by our intimate relationship ( $\sigma v v \eta \theta \varepsilon i ́ \alpha \varsigma)$. I think it right to make this, our bond of love ( $\tau$ òv $\delta \varepsilon \sigma \mu o ̀ v$ 


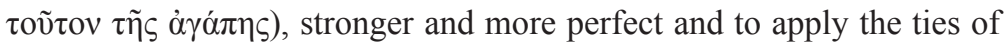
kinship to it, so that we may be joined in two ways, forging a family con-

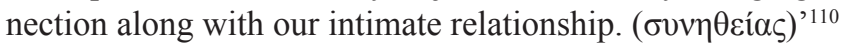

Nikephoros ultimately followed this advice, ${ }^{111}$ and we note that the word Bardas employs to describe the men's intimate relationship, synetheial $\sigma v v \eta \theta \varepsilon i ́ \alpha$, is capable of designating both close friendship and sexual relations. ${ }^{12}$ Accordingly, then, two generations of men in this saint's life have strong relationships with other men, and the depiction of these connections have in the case of Nikephoros and Bardas hints of corporeal closeness and, in the case of Theodore and Baanes, bold sexualising imagery. The conclusion to draw here is that intimations of sexual behaviour, and even strong images of carnality, are not scandalous in ecclesiastical contexts. ${ }^{113}$ The relative liberality in the penitentials and ecclesiastical writings and the non-enforcement and mechanical reiterations of the civil enactments form the essential background to reading Symeon's writings whenever his attention turns to same-sex relations between men. Indeed, allowing the (perhaps lighter than expected) weight of homoeroticism its full impact clears the way for a reader now to see Symeon's audience seeing in the parable a statement on the 'unmarried and notoriously celibate' emperor Basil II. ${ }^{114}$ It was not a serious charge to make and metaphors such as these were allowable.

\section{Basil as Symeon's referent}

An understanding that same-sex desire and behaviour were likely and not weighty things for Symeon to discuss is only a precondition for seeing Basil in the parable's emperor. This referentiality must be argued. The bases for the argument to come will be the fact of Basil's bachelorhood, the political situation in his reign, and Symeon's milieu which featured diffusion of his influence and writings among monks and laymen in the capital.

Basil's decision not to wed and play a direct part in the continuation of the Macedonian line was a momentous one. Much attested among the politically powerful, ${ }^{115}$ marriage was important, to say the least, in the empire at the time. ${ }^{116}$ Not exempt, an emperor was expected to take a wife. The second book of the chronicle of Theophanes Continuatus, a narrative of ninth-century emperors completed probably in $958,{ }^{117}$ has an episode from the reign of Michael II (820-829) in which this expectation is articulated directly. The anonymous author of this work, perhaps Theodore Daphnopates, ${ }^{118}$ who was in any case writing from the heart of Constantine VII Porphyrogennetos' court, tells how Michael compelled the senate to beg him to remarry after his first wife had died:

[The senate, prompted by Michael,] was saying, 'it is not possible for the emperor to live without a wife or for our wives to be deprived of their mistress and empress. ${ }^{119}$ 
And so, his hand, as it were, forced, ${ }^{120}$ Michael took the hand of Euphrosyne, daughter of Constantine VI (780-797): ${ }^{121}$ an emperor must be married.

From marriage come children of the blood. Possession of Macedonian blood drove political calclulations. This blood surely kept Basil and his brother safe during their minorities when Nikephoros II Phokas and John I Tzimiskes reigned. Blood similarly safeguarded Constantine VII and made him marriageable, as his union with Helena Lekapene, daughter of Romanos I shows. The extension of the Macedonian dynasty through the marriages of Basil's niece Zoe Porphyrogennete in the eleventh century also argues for the blood's importance. One can only imagine the pressure to marry that Basil, star of the fifth generation of the dynasty, resisted.

Not only securing the continuation of the line, marriage could be a powerful bargaining chip. Basil could have married a woman from a powerful family to create an alliance, as his grandfather did when he married Helena Lekapene. Older scholarship generally saw Basil as opposed to the artistocracy as a whole, and so such a move seemed unlikely on these terms. ${ }^{122}$ Recent scholarship has suggested Basil's opposition to the major families was selective. ${ }^{123}$ Hence, marriage to a woman from one of the families he favoured, say, the Skleroi, is conceivable. However, choosing a wife from one family would have created disappointment in the others. But Basil could have blunted disappointment by not playing a favourite. He could have married a woman of low status. His father, for example, married a comparative nobody, Anastaso in 955 or 956, who took the name Theophano. ${ }^{124}$ In the previous century, Basil I's wife, Eudokia Ingerina, was also not lofty. ${ }^{125}$ In this way, Basil also could have avoided entanglements with powerful in-laws. ${ }^{126}$ But neither a strategic marriage nor one to a nobody occurred, and neither is there any report of illegitimate issue, which had also been heard of, most famously in the person of Basil's own great uncle, Basil the parakoimomenos, who was the illegitimate son of Romanos I Lekapenos.

There is a final consideration bearing on Basil's refusal to wed which we must not lose sight of: marriage between man and woman is a place of desire and sex. ${ }^{127}$ It was well known, of course, that marriages, especially imperial ones, were about continuation of the line and alliance, but we also read that a beautiful empress attracted desire. Eudokia Ingerina entranced Michael III before he had to give her up and hand her over to Basil the Macedonian. ${ }^{128}$ Basil II's greatgrandmother, Zoe Karbonopsina (Zoe 'of the coal-black eyes') had a name which advertised her bewitching qualities. Basil's mother, the beautiful Theophano, ${ }^{129}$ was said to have awakened strong desire in her second husband, Nikephoros II Phokas. ${ }^{130}$ The corporeal rewards to being married were known.

Basil's bachelorhood in and of itself, then, creates a number of visibilities which predispose a reader now and a reader in the eleventh century to see him in Symeon's emperor. Basil was manifestly bucking the expectation that an emperor wed and continue the imperial line through begetting sons. He also refused a salient connection with another family that would have occurred through marriage to and the bedding of one of their women. Finally, to the extent that marriage was 
seen as the site of enjoyable sexual activity with a woman, he was visibly refusing that also. Given that it was possible for him to wed 'low' and avoid entanglements that, say, lofty in-laws might bring, the full-on force of these visibilities generates a question about the nature of his sexual desires. As discussed above, previous scholarship was happy to provide the answer of asceticism, but this is not a water-tight case and actually does not answer the question. If it is assumed that he was refusing sex, what kind of sex was he refusing? At this moment, the parable of Symeon becomes interesting. It provides a reading of the desire of the emperor: he is at least some of the time, if not more than that, interested in homoerotic encounters. This reading becomes more convincing when we consider the political situation in Basil's reign.

Basil struggled with rebels early in reign. He forgave some and punished others. The emperor in the parable 'over-loved' (i $\pi \varepsilon \rho \eta \gamma \alpha ́ \pi \eta \sigma \varepsilon v)$ a rebel. Does the parable provide a likely metaphor, given Basil's unmarried state, for this favouring that came to some, and not to others - others who would have found imperial forgiveness excessive? For example, Basil was surprisingly mild to one rebel, Bardas Skleros, ${ }^{131}$ and his son, Romanos, took a place in Basil's inner circle. Skylitzes reports that after the fall of his uncle, Basil the parakoimomenos, Basil needed new advisors, and he found one in Romanos Skleros:

After he had received him with exceedingly friendly intention and excessive joy, he [Basil] honoured this one [Romanos] as magistros and he was using him as an advisor in every aspect of his warring ... he [Basil] deprived of the counsel of him [Basil the parakoimomenos] and needing friends and allies in his struggles, at the time truly welcomed Romanos, knowing him to be a man quick-witted, energetic, and just the one for the things of war. ${ }^{132}$

The Phokades, and others in a similar position, may have felt the emperor 'over-loved' some rebels. The head of Bardas Phokas, torn from his dismembered body, ${ }^{133}$ took a trip to Constantinople and then to Asia Minor after his revolt ended. ${ }^{134}$ And just prior, Basil either had Kalokyres Delphinas ${ }^{135}$ 'hanged on wood'136 or impaled. ${ }^{137}$ His legislation against aristocratic interests, e.g. the law against the 'powerful' (dynatoi) from 996, ${ }^{138}$ would not have been perceived as showing love, much less 'over-love'. But what is to be noted, and which is supported by recent scholarship on Basil's reign, is that his opposition to the magnates was a sometime thing. ${ }^{139}$ From the point of view of someone not favoured, it could be said Basil played favourites. We may imagine that the extravagent forgiveness of some in the eyes of those not so honoured would have been galling. Symeon's emperor's carnal forgiveness is a metaphor for the favour Basil showed to some of his former enemies.

But this argument that Basil could be perceived as the referent in the parable depends additionally on seeing Symeon commenting on current politics in his oration. It is plausible to see him doing this for a number of reasons. In the first 
place, Basil had been the emperor for a long time by the time the Orationes Ethicae were written in the first decade of 1000s. Any reference to an emperor will encourage a reader or listener to compare and contrast Basil to the emperor appearing in the text. Second, Symeon had been struggling with Basil and his representatives, and the marks of struggle have been seen in the Orationes Ethicae. Darrouzès remarks that the Orationes Ethicae 'sont en grande partie une œuvre de controverse ou du moins composée durant une période de controverses'. ${ }^{140}$ The struggles, as noted above, were these: Symeon lost his monastery, St. Mamas; ${ }^{141}$ he got in trouble for fostering what was seen as inappropriate rites to the memory of his mentor, Symeon Eulabes; ${ }^{142}$ he even stood trial for heresy. ${ }^{143}$ All this happened in the decade or so prior to the writing of Oratio Ethica 10. A critical perspective on the emperor becoming visible in Symeon's works would not have been and is not surprising. Furthermore, the parable of the forgiveness of the rebel is not a singular event in Symeon's works. Emperor and imperial court appear elsewhere in his works.

Ambivalence and complexity characterise Symeon's metaphoric use of the emperor and his court. On the one hand, the magnificence and power of the emperor made imperial favour an apt metaphor for desirable divine interventions, such as God's grace, as seen in the parable from Oratio Ethica 10. On the other hand, Symeon shows an interest in bringing emperors down to earth. ${ }^{144}$ The carnality of the parable is an illustration of this. Reading other references by Symeon to the emperor together with the parable, we see that he finds emperor and court useful metaphors for divinity but also all too human and of this earth at the same time. Indeed, the image of the emperor in Symeon's thought is ambivalent, exhibiting idealising and critical perspectives simultaneously. What this means is that the emperor in the parable with the rebel is a figure that embodies both God and an actual emperor, the latter of whom will be human and fallible, indeed the latter predominates in other examples from Symeon's works.

At Catecheses $2.107-109,{ }^{145}$ Symeon critically observes that the earthly emperor has no time for the poor, cannot bear to look at them, and is no better than arrogant rich men are. ${ }^{146}$ Catecheses $4.470-472$ is also critical: 'the emperor separate from his army becomes weak and vulnerable to all and sundry and no longer appears to be emperor'. ${ }^{147}$ Making reference to 2 Samuel 12, Symeon counsels in another catechesis that emperors (and other leaders) would do well to keep in mind that king David admitted his fault to Nathan and fell to the ground before him (the implication being that this advice from the Septuagint is not followed as often as it should be). ${ }^{148}$ A final and significant example from Symeon's works features not only ambivalence about the emperor (and his court) but also employs the verb 'over-love' $v \pi \varepsilon \rho \gamma \alpha \pi \alpha$, which is the same word used in the parable from Oratio Ethica 10.

Symeon wrote the Capita Theologica, a work of practical instruction on virtues and vices, after he was removed as hegoumenos of St. Mamas. ${ }^{149}$ In the eighth section of the second book of this work, he compares the pious elation a monk feels when 'called aloft to the height of contemplation of the Holy Spirit'150 
to the pleasure the emperor can give when he bestows earthly position and riches. At the end of the comparison, Symeon compares donning Christ to being clothed in imperial purple:

For he [the monk who has withdrawn from the world ${ }^{151}$ ] looks always upon the grace of the Spirit shining around him, this grace which is called a raiment and imperial purple, or rather it is Christ himself, if [we care to say, and of course we do, that] those who have faith in him are clothed in him. ${ }^{152}$

But this is not the entirety of the comparison. Symeon earlier describes the promotion in detail. Characteristically for Symeon, his comparison overshoots the mark by describing a scene whose corporealities make it an imperfect metaphor, and, hence, a text that additionally has criticism of the earthly emperor on its mind:

Just as the one who has been raised from the most extreme poverty by the emperor, who has been clothed by him in brilliant office and a shining robe, who has been ordered to stand in his presence, just as this one looks upon the emperor with desire ( $\mu \varepsilon \tau \grave{\alpha} \pi$ ó $\theta$ ov), over-loves

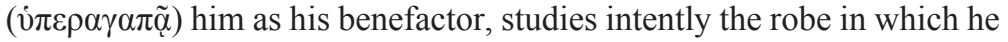
has been clothed, knows well his office, and thinks about the wealth that has been given to him. ${ }^{153}$

The emperor can raise up a man who is a nobody and clothe him in office and robes. This benefaction awakens intense regard (desire/ $\pi$ ó $\theta$ os) in the one so honoured and he even 'over-loves' (i் $\pi \rho \alpha \gamma \alpha \pi \tilde{\alpha})$ the emperor in return. As in the parable from the tenth Oratio Ethica, though not in as graphic a manner, Symeon calls to mind erotic desire through the use of the noun pothos. Even

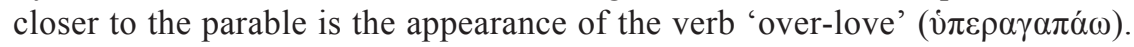
In contrast to the passage from Oratio Ethica 10, however, 'over-loving' does not rain down from above, but rises up from below. If we read this passage from the Capita Theologica together with the parable in order to come to an understanding of Symeon's ideas about desire and promotion in the imperial court, we can make two points. First, 'over-loving' is something that does not belong solely to superior or inferior but can be expressed by either. ${ }^{154}$ Second, the imperial court is a place of excess, for, as with the parable, the picture of relations in the court has a surfeit of things of this world that make it a metaphor that does not quite fit. 'Over-loves' (ं் $\varepsilon \rho \alpha \gamma \alpha \pi \tilde{\alpha})$ conveys some disapproval. The one, whom the emperor has promoted, loves his royal highness, the gorgeous clothing, office and wealth to come more than is right, hence the 'over' (vं $\pi \dot{\varepsilon} \rho)$. Is Basil's court, missing an empress and therefore skewed to homosociality, visible here?

Ambivalence, accordingly, is present, or perhaps it is better to say that Symeon has his cake and eats it too. The comparison to imperial privilege and raiment 
makes the attainment of grace and Christ the ne plus ultra, on the one hand, while, on the other hand, a critical stance to these marks of worldly advancement is also visible. The courtier has reached a summit of earthly ambition and so the metaphor is effective. But the courtier so honoured does not merely love, he 'over-loves'. He places too great a value on the things of this world. Same-sex desire with its worldly corporealities complicates this picture in a similar fashion, especially for those who live in Symeon's thought world and/or may know the parable from Oratio Ethica $10 .{ }^{155}$

And so we come to a key assertion. It is all well and good to demonstrate that Symeon was capable of twice constructing metaphors of imperial favour metaphors containing same-sex desire and 'over-love' - that both gesture in the direction of God and divine grace, and, yet, venture criticism of the emperor at the same time. In the absence of an audience, such a thing would be but a dead letter. But Symeon's writings were not solipsistic and removed from life. We must not imagine that his thought world was limited to him or to a small circle of readers or listeners. Symeon was almost never far away from action in the capital. Indeed, he was within the city walls for all those years at St. Mamas, and later was just across the Bosporos at Paloukiton at St. Marina's. Furthermore, the secondary literature discusses much interaction between monks and laymen. ${ }^{156}$ As an estimable ecclesiastical leader, Symeon was spiritual father not only to monks in his own establishment, but also maintained pastoral connections to men in the world. ${ }^{157}$ As noted above, Christopher Phagoura, a layman with whom he was connected, set him up in his oratory at Paloukiton. ${ }^{158}$ Politics did not cease at the monastery door, indeed the door was open to traffic coming in and going out. Lastly, it seems quite likely that the Orationes Ethicae were addressed to an audience both monastic and secular. ${ }^{159}$ This was a broad audience for whom Basil would have been the only emperor in living memory: any parable about an emperor would have been measured against Basil for similarities and differences at least momentarily. It is logical in light of the facts about Basil, the political situation, and the context within which Symeon was writing to assume that the parable from Oratio Ethica 10 could have been seen as commentary on the current emperor's policies and sexual life.

\section{Conclusion}

Symeon's emperor is not only an idealised figure. He is both an idealising metaphor and, at the same time, liable to criticism for being too much of this world. When Symeon criticises an emperor, at that moment the current holder of the throne, Basil II, comes into view. And so Symeon provides a reading of Basil's bachelorhood. Symeon would have had reason to wish to render some criticism, and his excessive portrayal in the parable from Oratio Ethica 10 in a variety of ways encourages the reader to form a question about bachelor Basil's desire: did he spend the time he saved by not being married with other men? 
The old idea that he spent this time in celibacy dedicated to God has weaker support. Ademarus is not persuasive due to demonstrated ignorance and mendacity. Also, far away and from another milieu altogether, he was not capable of understanding the evolving attitudes toward same-sex desire in Constantinople during these centuries. Psellos speaks of Basil's grimness and rather more than that, if we read him carefully with Crostini and Garland. We likely have a hint of Basil's unmarried state in the advice Psellos reports Bardas Skleros gave to Basil. But that is all. In contrast, Symeon's parable has a possible referent in Basil because of the question about desire his bachelorhood posed, his differential treatment of rebels, and the milieu in which Symeon wrote. We cannot and I do not want to rule out a possible taste for women on Basil's part, but we have no evidence of that and instead have an indication, via Symeon, that he had same-sex interests. Symeon had an axe to grind and it is plausible that he might have liked to deliver a chop - a chop, it must be understood, that would not be devastating, but rather to point out a carnal failing. The imperial court, of which he had experience earlier in his life, ${ }^{160}$ was too materialistic in its practices and should hardly be telling him what to do. Exclusively homosocial, with no wife in sight, the court was liable to 'over-loving' excesses. We should view Symeon's critique as something of a throwaway. It was not devastating and illuminates our understanding of same-sex desire among men in Byzantium at this time.

\section{Notes}

1 I thank Shaun Tougher for the opportunity to speak and write on Basil II and for his understanding and guidance. I also thank Stephanie Cobb, Derek Krueger, Nancy Rabinowitz, and Steven Smith for their advice.

2 All translations are my own.

3 His brother, Constantine VIII (1025-1028), was also emperor throughout this time, but all sources agree that he was side-lined until Basil's death: see for instance Tougher 2013: esp.316-318. Be it noted that Constantine married.

4 Psellos, Chronographia 1.19-21, narrates the fall of Basil the parakoimomenos. At 1.3 , he tells of happier days for the two Basils, great-uncle and grand-nephew. For more on Basil the parakoimomenos, see Brokkaar 1972; Tougher 2008: 138. For discussion focusing on his interactions with Basil II, see Crostini 1996: 59-64; Garland 1999a: 326, 326 n.20; Holmes 2003: 58-61; 2005: 469-474; 2006: 331-333.

5 For a classic statement of Basil's success, see Ostrogorsky 1968. Others, e.g. Angold 1997 and Holmes 2005, are sceptical to varying degrees, wondering if the success of the empire under Basil was as solid as it has sometimes been made out to be. See Holmes 2005: 448-543, for narration of his reign, including the major campaigns. For legal enactments, see Svoronos 1994: 185-217. I should note here too that Holmes 2003 and 2005 and Sifonas 1994 have provided welcome nuance to overly schematized accounts of Basil's reign that see him as relentlessly attacking the aristocracy as a whole, for he opposed some families and not others.

6 Leo the Deacon, Historia 5.3; Shepard 2003: 15; Tougher 2013: 307.

7 Holmes 2005: v. In similar fashion, Garland 1999a: 321, calls Basil 'something of an enigma'. 
8 E.g. Garland 1999a: 321, states that the question of Basil's non-marriage has been (close to?) a non-issue since 1975: 'A study by Arbagi (1975) has helped resolve the problem of why Basil never married. . .'.

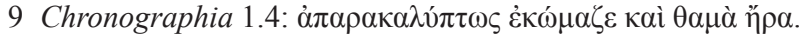

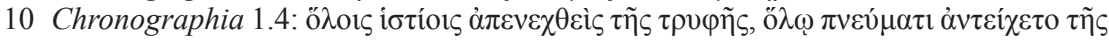
$\sigma \pi \mathrm{ov} \delta \tilde{\eta} \varsigma$.

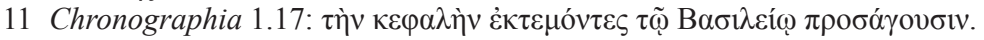

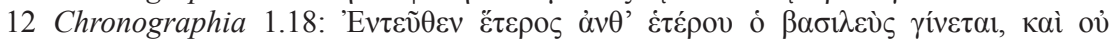

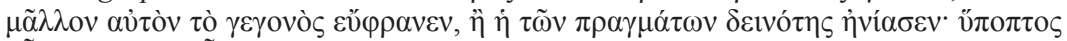

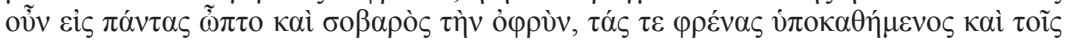

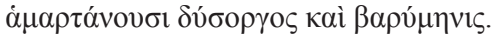

13 Chronographia 1.22.

14 Chronographia 1.32.

15 Chronographia 1.29; Crostini 1996 shows that Psellos is being particularly tendentious here.

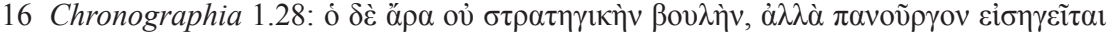

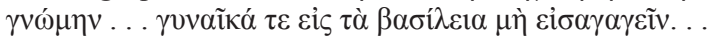

17 It is possible that a reader may think this translation is not correct and that Skleros merely counsels against having a woman at imperial strategy sessions, as Sewter in his translation from 1979 seems to believe. This, however, is to understand the passage in an unnecessarily laboured way. The passage's probable reference to advice to Basil to persist in his bachelorhood is strongly supported by reference to the $L S J$. We read the following, which is as close to conclusive as can be imagined, at

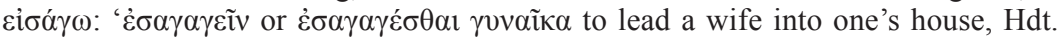
5.40, 6.63'. The reference to Herodotus seals the deal, as Psellos' audience was cultivated. Furthermore, ta basileia was a favoured term for 'palace' from early times in Greek, and again this meaning would be a predominant one if we allow the fact of Psellos' audience's cultivation its proper weight. For the record, this passage has not been mentioned in any scholarship that I have seen that has addressed Basil's bachelorhood.

18 Crostini 1996; Holmes 2003: 61-62; 2005: 31-35, 516-517; Garland 1999a: 339-342, brings to light ways in which Psellos presents Basil as a comment on the eleventh-century emperor Isaac I Komnenos (1057-1059).

19 Crostini 1996: 66-71.

20 Crostini 1996: 70 (cf. Van Opstall 2008: 26). Estimable intellects are to be found among Basil's associates. Nikephoros Ouranos and Leo of Synada are two examples. See Darrouzès 1960 for the letters of Nikephoros Ouranos, whose letters are urbane and well-written. Darrouzès $1960: 48$, asserts '[his letters] suffisent pour nous dévoiler le cœur noble et l'esprit cultivé de Nicéphore Ouranos'. See also Vinson's 1985 edition of Leo's letters.

21 Garland 1999a. Chronographia 1.20, 27, and 33.

22 Holmes 2003: 61, is the less direct; Holmes 2005: 34, is the more direct.

23 Holmes 2005.

24 Holmes 2005: 463-470, argues persuasively that understanding Basil as opposed to all the aristocratic families, full-stop, is incorrect. It was rather the case that he was against some families and a key issue in the maintenance of his authority was not so much land and revenue as control of the army (cf. Holmes 2003: 48-51, and Sifonas 1994).

25 Note that Psellos offers elsewhere a brief sketch of Basil's grim character: Historia Syntomos 106.

26 Angold 1997: 5; cf. Wolff 1978: 144, '[Basil's] personal asceticism is historic fact'.

27 Treadgold 1997: 513. 
28 Chronographia 1.4.

29 Treadgold 1997: 519; Holmes 2006: 336.

30 Tougher 2013: 307, 'It seems likely that his decision was taken on religious grounds, rather than because of sexual preference, but the fact remains that this was a highly unusual act for a ruler. . '; cf. Crostini 1996: 76-77.

31 Arbagi 1975; Garland 1999a: 321; Holmes twice reports that others have seen a vow by Basil as an explanation for his failure to wed (Holmes 2006: 336; 2005: 45 n.60). Magdalino 2003: 263-265, suggests that Basil's bachelorhood and religious interests be associated with general feelings in the empire that the millennium was going to bring with it the end of the world; he was unmarried because the end of days was nigh.

32 Crostini 1996: 74-75 (speaking of Chronographia 1.18): '[at this point in the Chronographia, Psellos only means to speak of] the emperor's zealous undertaking of duty, his business of governing of the state. No fanciful dedication to a religious lifestyle is here implied'. In spite of this, Crostini 1996: 76-77, believes that Psellos elsewhere (at Chronographia 1.32) implies that Basil was acting according to religious scruples when his behaviour changed from fun-loving to grim. She even calls it a 'religious conversion' (76). The narrative of Psellos is complex and Crostini perhaps argues against herself here.

33 Chronographia 1.28 .

34 For background on Ademarus, see Wolff 1978: esp. 139.

35 See for example Tougher 2013: 307; Holmes 2006: 336, 339; Holmes 2005: 19, 45; Stephenson 2003: 73; Garland 1999a: 321.

36 Among the errors are the omission of the Battle of Kleidion, misconceptions about the personnel of the Bulgarian leadership, and the belief that Basil's struggles with the Bulgarians began around the year 1000 (they began in the 980s). For discussion of Ademarus' mistakes, see Arbagi 1975: 43-44, and Wolff 1978: 143-144.

37 Chronicon 3.32: [B] asilius imperator super eos nimis irritatus, voto se obligavit Deo monachum fieri, si Grecis gentem Bulgarorum subderet ... sicut voto promiserat, habitum monasticum greca figura subterindutus in reliquum est omni vitae suae tempore, a voluptate et carnibus abstinens, et imperiali scemate extrinsecus circumdabatur.

38 Arbagi 1975: 44.

39 As noted above, Wolff believes that the severe and ascetic Basil's vow was fictitious.

40 Wolff 1978: 156-158.

41 Tougher 2013: 307, remarks that there was one other emperor who did not wed: Constans I (337-350), son of Constantine I. It is interesting to note in the context of the present investigation that there was discussion in the sources about Constans' interest in same-sex encounters. See my discussion, with bibliography: Masterson 2014: 24 n.53.

42 Psellos, Chronographia 1.28.

43 For more on Symeon's life, see Messis 2014: 144-148, McGuckin 2005: 1996, and Turner 1990: 16-36, whose narratives in turn depend on Niketas Stethatos' life of Symeon (written in the decades following the death of Symeon in 1022), as rationalized by Hausherr 1928. For a strong statement of the fact of Symeon's eunuch status, see Messis 2014: 144-148.

44 Niketas Stethatos, Vita Symeonis 3; Turner 1990: 18; McGuckin 1996: 19.

45 Catecheses 22.24-28: '[ $\mathrm{He}(=\mathrm{I})$ had] a young man's beauty and possessed frame, personality, and gait that were like a vision, so that from these [aspects] some men even had raunchy suspicions about him, and others were only looking at his outer

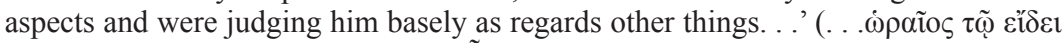

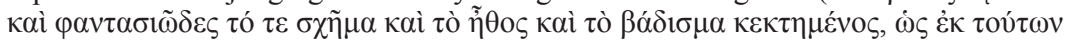




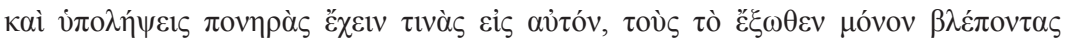

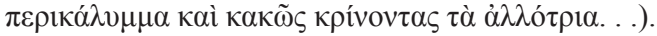

46 See comment by McGuckin 1996: 19, 'a successful and somewhat rakish youth'.

47 Darrouzès 1966: 8-13, provides a tidy presentation of the contentious atmosphere that most likely surrounded Symeon when he wrote the Orationes Ethicae.

48 Niketas Stethatos, Vita Symeonis 59. Note that Niketas depicts Symeon as resigning from his leadership role voluntarily on account of his love of quiet (ó है $\rho \omega \varsigma \tau \tilde{\eta} \varsigma$

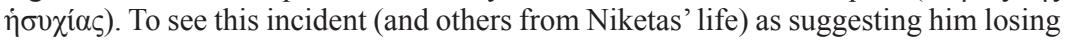
the monastery involves reading through panegyrical content (a necessary if precarious operation). At the moment I follow Turner 1990: 34.

49 Niketas Stethatos, Vita Symeonis 72.

50 Niketas Stethatos, Vita Symeonis 75-77.

51 Niketas Stethatos, Vita Symeonis 95.

52 Niketas Stethatos, Vita Symeonis 100.

53 See Messis 2014: 145-146, for a chronology that places Symeon's travails a decade or so earlier.

54 Krueger's suggestion (2006: 100) that the parable might recall the political situation in Basil's reign was an important inspiration for this chapter. I will note here that Krueger's goal diverges from mine. Krueger argues that the carnality between emperor and rebel be seen in the context of Symeon's interest in guiding the ascetic practices of his monks with lively and likely imagery; the evocation of homoerotic desire 'is a powerful tool in the making of his monks' (Krueger 2006: 118). It is my hope that my analysis be seen as complementary to his.

55 Oratio Ethica 10.229-231.

56 Oratio Ethica 10.646.

57 Oratio Ethica 10.235-273.

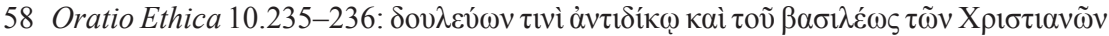
$\dot{\varepsilon} \chi \theta \rho \tilde{\varphi}$.

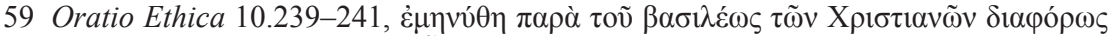

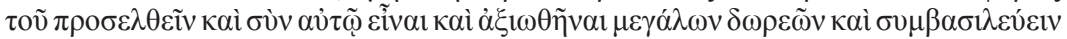
$\alpha \hat{\tau} \tau \tilde{\omega}$.

60 Oratio Ethica 10.241-243.

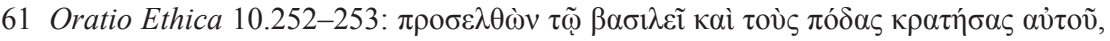

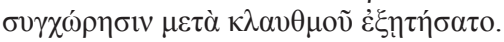

62 Luke 15:20.

$63 \mathrm{X} \lambda \alpha v i \delta \delta$ iov is the Greek translation of paludamentum, which is the emperor's cloak ( $L S J, \chi \lambda \alpha$ víiovo).

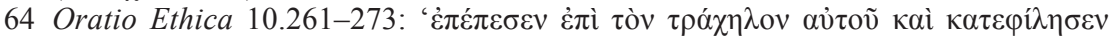

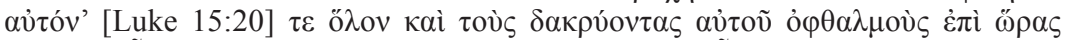

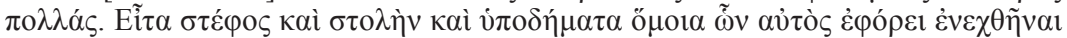

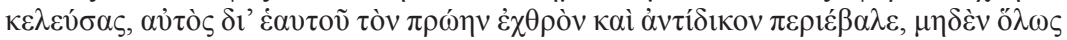

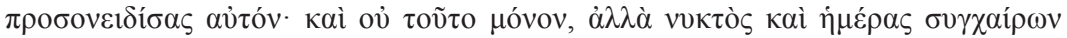

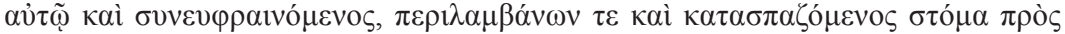

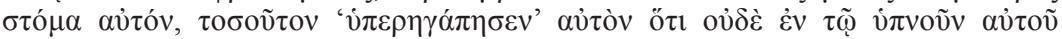

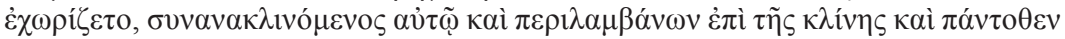

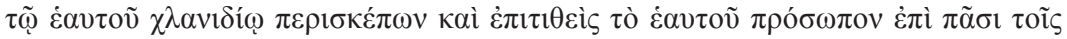
$\alpha$ $\tau 0 \tilde{} \mu \varepsilon \dot{\lambda} \lambda \varepsilon \sigma ı v$.

65 See Krueger 2006: 101, on the anxiety this passage has awakened in some of Symeon's modern commentators.

66 Krueger 2006: 99.

67 Krueger 2006: 109; Hymn 15.161-162.

68 Krueger 2006: 108-109. 


\section{MARK MASTERSON}

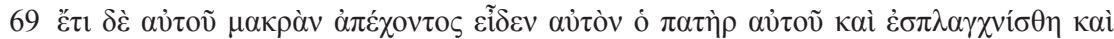

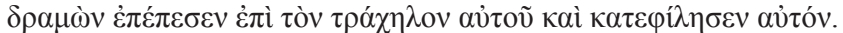

70 Niketas Stethatos, Vita Symeonis 34, mentions that St. Mamas was founded by Maurice when he discusses Symeon's renovations to the monastery.

$71 P G$ 89: 1112-1116. This work exists in two nearly identical versions. The parable can also be found at $P G$ 89: 1140-1142. I limit my discussion to the first version. Darrouzès 1967: 279, drew my attention to this parable from Anastasius in a note appended to Symeon's parable at lines 229-234.

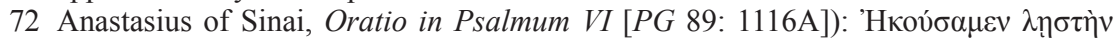

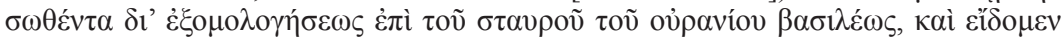

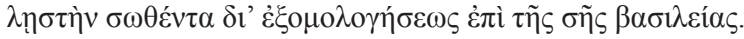

73 The coming remarks on various loci in Symeon's works owe much to Krueger's discussion from 2006.

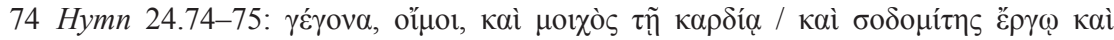
$\pi \rho \circ \alpha\llcorner\varepsilon \dot{\sigma \varepsilon \varepsilon}$.

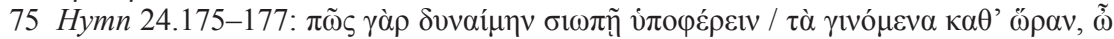

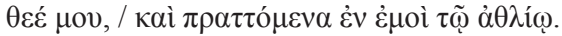

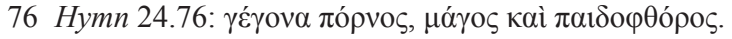

77 What is rhetoric and what is reality when Symeon confesses to so much are difficult questions. See Krueger 2006: 116; Golitzin 1998: 26-27; Turner 1990: 27-29.

78 E.g. Turner 1990: 28-29.

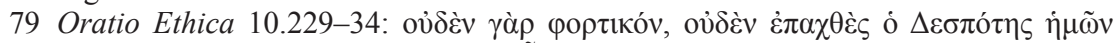

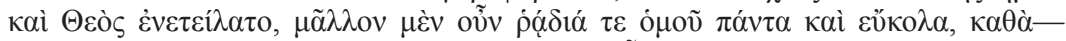

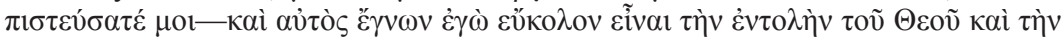

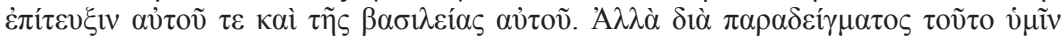
$\dot{v} \pi \mathrm{o} \delta \varepsilon \dot{\xi} \xi \omega .$.

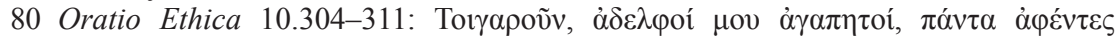

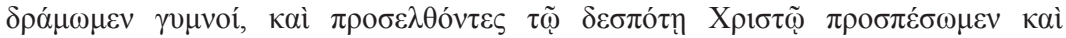

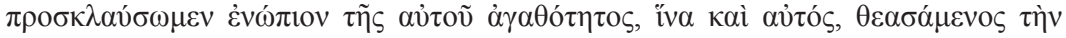

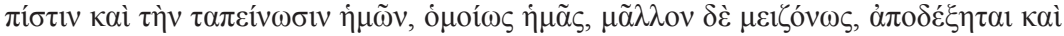

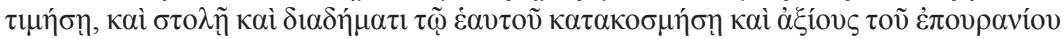

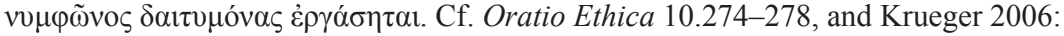
107. Note that Krueger and I see the nudity differently: for Krueger the nudity describes the casting off of desire, for me the nudity is revelation of desire.

81 Krueger 2006: 101.

82 Laiou 1992: 78.

83 Prefiguring this comment, Mullett 1988: 11 n.41, notes that possible sexual expression between men was not as weighty an issue as we now might imagine it was. Pitsakis 2008: 9, underscores the nonchalance in the sources about sex between men, while being uncertain whether this means that same-sex desire was thought unimportant or if there was wide-ranging tolerance that we, dealing with the weight of our history, can hardly understand now. Smythe 1999: 144, followed up Laiou's analysis, but then speaks of Byzantium as the 'first closet society', citing Sedgwick 1990. As the closet in Sedgwick's formulation is a structure of paranoid concealment with the possibility of catastrophic revelation, it does not suit this Byzantine evidence.

84 Laiou 1992: 68; Messis 2006: 779 n.170; Pitsakis 2008: 8.

85 Messis 2006: 781.

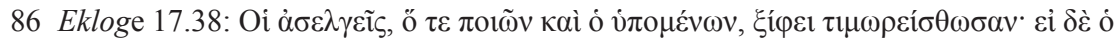

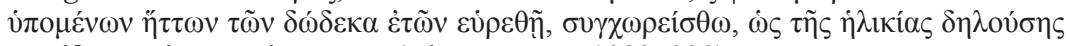

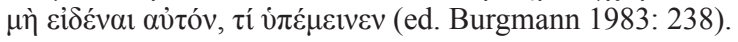

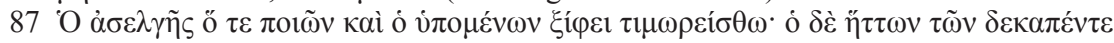

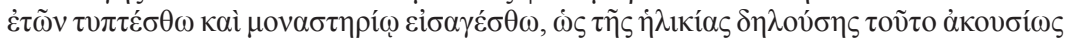

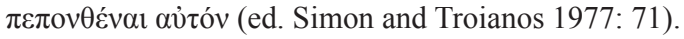




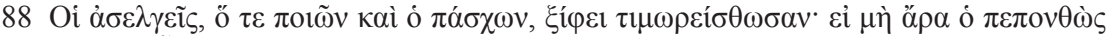

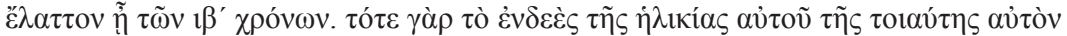
$\dot{\varepsilon} \xi \alpha \rho \pi \alpha ́ \zeta \varepsilon 1 \pi 01 v \tilde{\eta} \varsigma$ (eds. Zepos and Zepos 1931: 365).

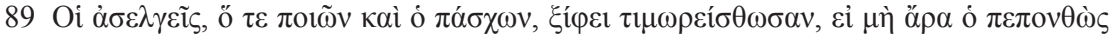

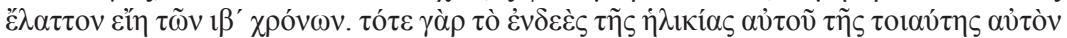

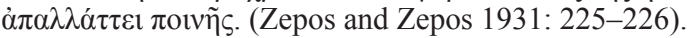

90 Troianos 1989: 35-37; Messis 2006: 776-778, 781.

91 See Joannou 1963: 147, and Rhalle and Potle 1854: 220, for Canon 62 (and Joannou 1963: 103-104, and Rhalle and Potle 1854: 110, for Canon 7, which gives the length of the penalty. Cf. Troianos 1989: 41; Messis 2006: 781-782.

92 Joannou 1963: 212-216; Rhalle and Potle 1854: 308-311. Cf. Troianos 1989: 42-43; Messis 2006: 782.

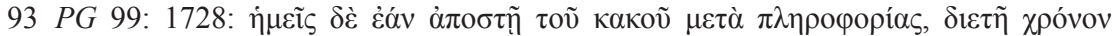

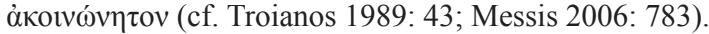

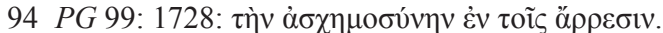

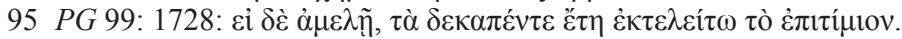

96 Arranz 1993: 20-22, who assembled an edition that contains two of the three canons to be discussed presently, attributes the collection to John the Monk and suggests that it could be as late as the eleventh century but prefers the ninth or early tenth, cf. Troianos 1989: 43, who does not believe the sixth-century patriarch wrote these canons either.

97 Troianos 1989: 43.

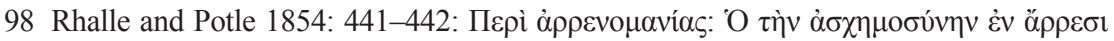

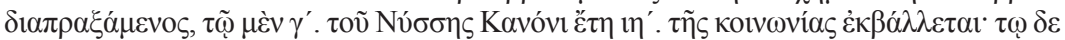

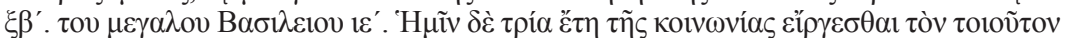

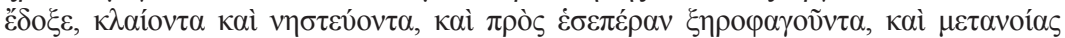

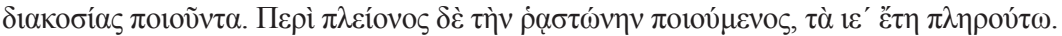

99 Arranz 1993: 72.2-8.

100 Arranz 1993: 72.9-12; elsewhere in these canons, and with possible inconsistency, sex against nature with a man (Arranz 1993: 68.10 and 14-15) nets simply a threeyear penance with no qualification.

101 Messis 2006: 786; Arranz 1993: 70.8, 70.21-72.1.

102 Arranz 1993: 50.26-32.

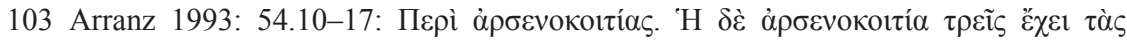

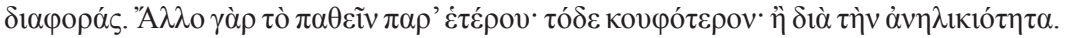

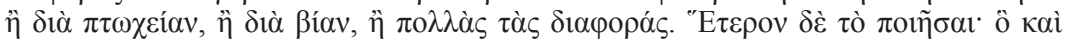

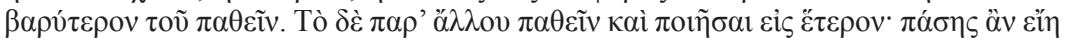

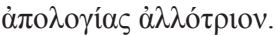

104 Morris 2016: 3, has the following to say about the impression the evolving attitudes of the medieval church can evoke: 'In terms of "gay sexuality," the historical practice of the [Eastern Orthodox] church is far from what many modern church members might expect it to have been'.

105 For the dating of the life, see Talbot 1996: 242-245.

106 See Rapp 2016: 220-222, for discussion of this life. I also thank her for drawing my attention to this work.

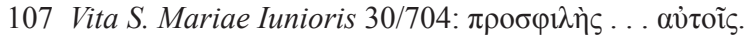

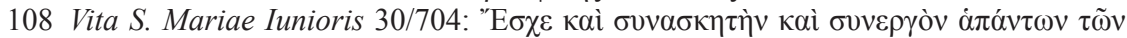

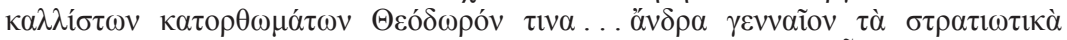

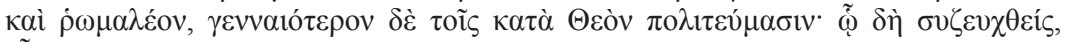

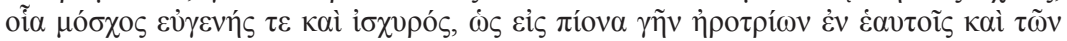

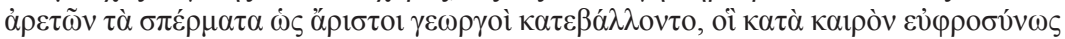

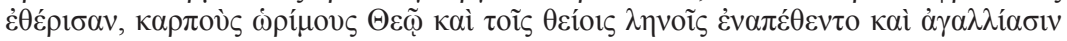

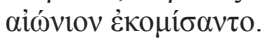




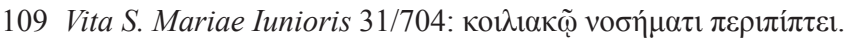

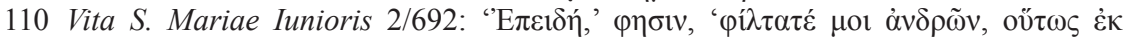

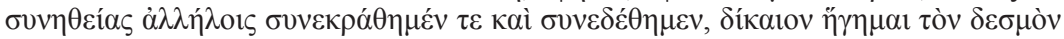

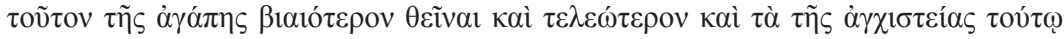

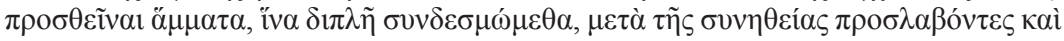

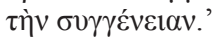

111 For the record, it was not good for Maria to have this man for a husband. Violent, Nikephoros beat Maria so badly (9/696) that she died from her injuries (10/696).

112 Talbot 1996: 256 n.52; LSJ offer up the following in its entry for $\sigma v v \eta \theta \varepsilon i ́ \alpha$ : 'sexual

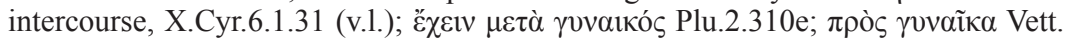
Val.288.23'.

113 It strikes me that this life needs to take its place as a central text on modes of interpersonal connection in Byzantium. Men and women become connected in marriage and men become connected through marriage, even as their relations, one on one, feature emotional and corporeal intensity. The regrettable violence of Nikephoros is worth some thought too: is there something to be said about his possible primary connection to Bardas and a marriage that was an afterthought?

114 Stephenson 2003: 61.

115 There were marriages that built a man's authority within the empire, e.g. the marriage of Nikephoros II Phokas to Theophano, Romanos II's widow, is one. The second marriage of Michael II, to be discussed below, qualifies. John I Tzimiskes' marriage to the sister of Bardas Skleros, an important military commander who later revolted against Basil, provides still another example (Leo the Deacon, Historia 5.5, 6.11, 7.3; Skylitzes, Synopsis Historion, John I Tzimiskes, chap. 5). There also were marriages (or proposed marriages) of Byzantine notables to foreigners. Basil and his brother were betrothed to Bulgarian princesses (Leo the Deacon, Historia 5.3; Shepard 2003: 15; Tougher 2013: 307). In 1005-1006, Basil arranged the marriage of Maria Argyropoulina - sister of the later emperor, Romanos III Argyros (1028-1034) - to Giovanni Orseolo (the son of Peter II, Doge of Venice) for the purpose of alliance (Skylitzes, Synopsis Historion, Basil II and Constantine VIII, chap. 25; Wortley 2010: 325 n.135). One need hardly mention Anna, Basil's sister, and her marriage to Vladimir of Kiev, or Theophano Skleraina's to Otto II (see for example Shepard 2003).

116 For discussion of the legislative background of marriage in Byzantine society, see Laiou 1992: 9-58, and Pitsakis 2000. For marriage among elite Byzantines, see Macrides 1992, Shepard 2003, Schreiner 1991, and, quite ad rem as general background to this chapter on Basil and his non-marriage, Tougher 2013. There also were moves toward having male members of the imperial house marrying foreign royalty in the tenth century. For example, Romanos II, Basil's father, was betrothed in 944 to Bertha, daughter of Hugh of Arles (Shepard 2003: 7). Basil II with some controversy married his sister Anna to Vladimir of Kiev: see discussion in Shepard 2003, and Tougher 2013. In any case the importance of marriage for the formation of connections that will enable familial flourishing, political power, and even alliances with foreign powers is clear enough from the histories of this time. Skylitzes' Synopsis Historion positively coruscates with marriages: Nikephoros II Phokas, chap. 2; John I Tzimiskes, chaps. 5, 7, 8; Basil II and Constantine VIII, chaps. 2, 17, 24, 25, 44.

117 Treadgold 2013: 165, 179.

118 As suggested by Treadgold 2013: 176-179.

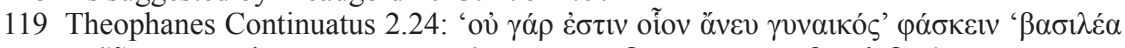

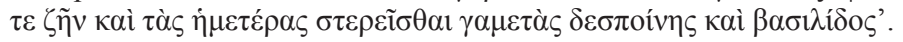

120 There is a further complexity to this story. The author, no friend to Michael, says that Michael wanted it to look like he loved his deceased wife so much that he had to be compelled to remarry: 'And so, when his wife had died and since he was wanting the 
opinion of the many to believe that inconsolable grief for her held [him]. . .' (Theophanes

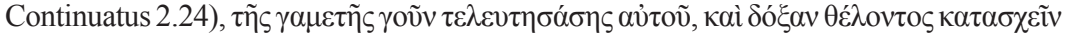

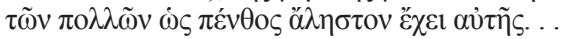

121 Theophanes Continuatus 2.24.

122 For bibliography and discussion see Holmes 2005: 21-29, and Sifonas 1994: 118 n.1.

123 See Sifonas 1994, and Holmes 2005.

124 Skylitzes, Synopsis Historion, sole reign of Constantine VII, chap. 7, reports that her name, prior to the assumption of the grand name Theophano, was Anastaso and that her background was not lofty; Wortley 2010: $232 \mathrm{n} .32$. It is possible that she was not as low as all that, see discussion in Garland 1999b: 126-127, 270 n.3. In any case, though, she was not as lofty as a Skleraina.

125 Symeon the Logothete, Chronicon 131.32 (ed. Wahlgren 2006: 248); Eudokia Ingerina was at first mistress to Michael III. Empress Theodora (his mother) and the logothete Theoktistos thought her unsuitable for Michael, making him marry Eudokia Dekapolitissa instead. Notably though, Eudokia's modest background and the unpromising beginning of her involvement in imperial circles did not stop her from becoming mother to the Macedonian dynasty.

126 Treadgold 1997: 519.

127 Schreiner 1991: 189, points out that in the ninth and tenth centuries beauty in an empress was often more important than lineage and, hence, alliance. Desire was, therefore, a possible consideration.

128 Both versions of Symeon the Logothete's Chronicon and the Chronographia of Pseudo-Symeon (all written in the mid-tenth century) speak of the intense desire Michael felt for Eudokia: Symeon the Logothete, Chronicon 131.32 (first version), ed. Wahlgren 2006: 248; Chronicon (second version), ed. Bekker 1838: 828.23, Istrin 1920: 11, Featherstone 1998: 427.25; Pseudo-Symeon, Chronographia 675.40 .

129 Leo the Deacon, Historia 2.10.

130 Skylitzes, Synopsis Historion, Nikephoros II Phokas, chap. 22, notes that Nikephoros and Theophano had sexual relations (synousia). Zonaras 16.28 reports

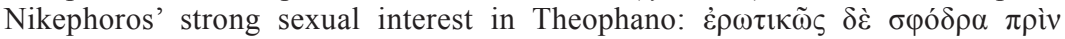

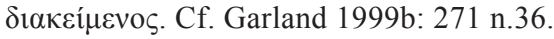

131 Psellos memorably relates the peaceable meeting Bardas Skleros and Basil had (Chronographia 1.28). Bardas Phokas died before he could have been forgiven by Basil (Psellos, Chronographia 1.16-17; Skylitzes, Synopsis Historion, Basil II and Constantine VIII, chap. 18) but it does not seem likely that he would have fared as well as Skleros did.

132 Skylitzes, Synopsis Historion, Basil II and Constantine VIII, chap. 16: ôv oṽ

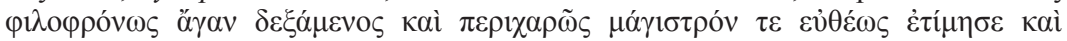

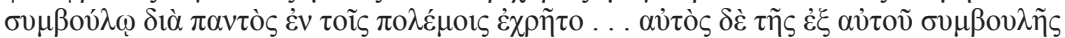

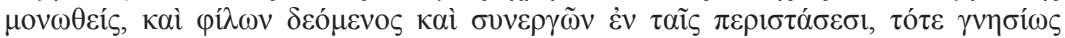

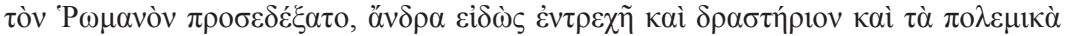

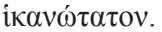

133 Psellos, Chronographia 1.17.

134 Leo the Deacon, Historia 10.9.

135 For more on Kalokyres Delphinas, see Talbot and Sullivan 2005: 216 n.87; Wortley 2010: 318 n.96.

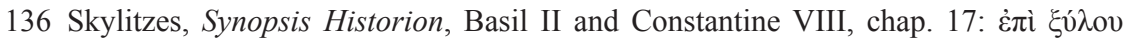
$\kappa \rho \varepsilon \mu \tilde{\alpha}$.

137 Leo the Deacon, Historia 10.9: $\dot{\alpha} \varepsilon \varepsilon \sigma \kappa o \lambda o ́ \pi ı \varepsilon \varepsilon$.

138 Holmes 2005: 461-462; Svoronos 1994: 190-217.

139 See Sifonas 1994, and Holmes 2005. 
140 Darrouzès 1966: 8. The secondary literature has discussions of the evidence of struggle in these orations: Darrouzès 1966: 8-13; McGuckin 1996: 27-31, and 2005: 186-187. See also Turner's biographical sketch (1990: 16-36). Turner 1990: 11 , believes the orations to be addressed to persons in and outside of the monastic context: 'These, apparently written works from the outset, were addressed to a wider public than the monks of Symeon's monastery. . '. Darrouzès 1966: 8, remarks that Symeon 'parle [in the Orationes Ethicae] en défenseur de la théologie mystique contre des adversaires indéterminés mais réels'.

141 Niketas Stethatos, Vita Symeonis 59.

142 Niketas Stethatos, Vita Symeonis 72.

143 Niketas Stethatos, Vita Symeonis 75-77.

144 Turner 1990: 21; Krivochéine and Paramelle 1963: 250-251 n.1, and 381 n.1; indeed, Krivochéine (252) says: 'En général, quand il parle des " rois terrestres », c'est presque toujours sans sympathie, quelquefois avec ironie et hostilité'.

145 Precise dating of individual Catecheses is not possible. They were directions to his monks and they date from the time when he was hegoumenos of St. Mamas, i.e. 980-1005 (Krivochéine and Paramelle 1963: 165).

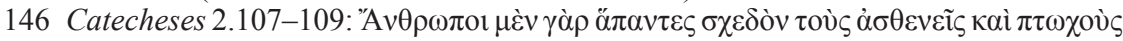

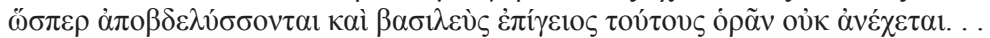

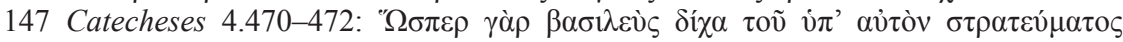

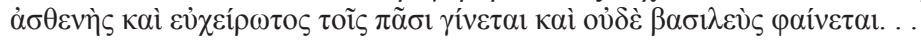

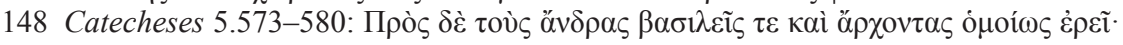

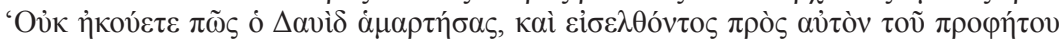

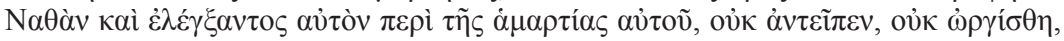

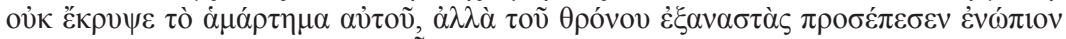

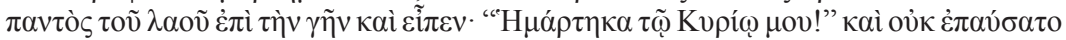

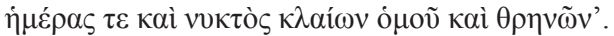

149 The date of the Capita Theologica is late in the decade of the 1000s, or even later than that (Darrouzès and Neyrand 1996: 10).

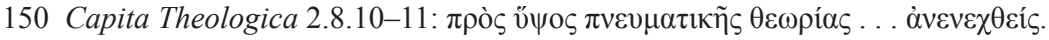

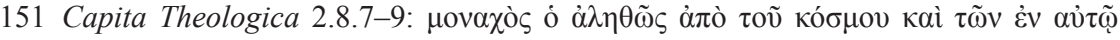

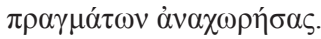

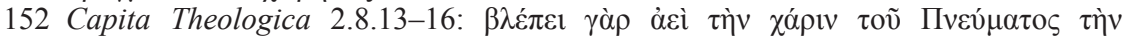

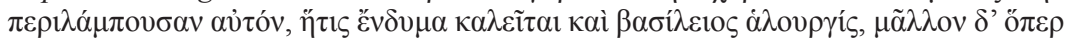

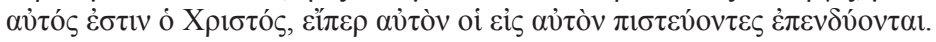

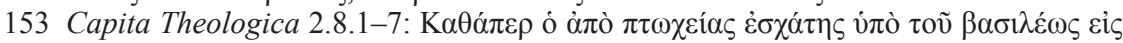

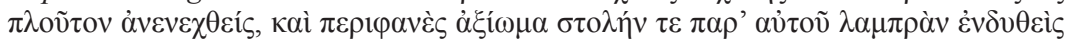

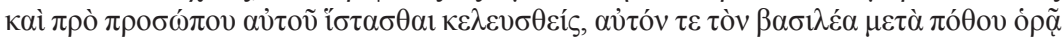

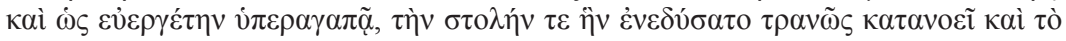

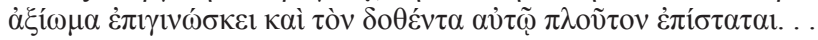

154 The fact that neither position has exclusive rights to 'over-love' puts the question to the assertion of Krueger 2006: 115, that the asymmetries asserted for ancient sexuality are operative in Byzantium.

155 Space will not allow discussion, but this picture of a courtier raised up by imperial interest recalls what Beck 1965 has to say about hetaireiai (gangs, comradeships). He discusses evidence in the chronicle of Theophanes Continuatus, and in other later histories, of groups of young men of obscure origin who make their way into association with imperial power, or even to the throne itself. These men are chosen for membership in these hetaireiai on the basis of shared interests in, say, hunting or horsemanship, and good looks (and hence possible same-sex desire) could be a factor leading to successful entry into a hetaireia (Beck 1965: 10; 16). Indeed, Beck 1965: 29, remarks 'der Charakter dieser Hetairien ist nicht durchwegs politisch'. The rise of 
emperor Basil I (867-886) is a prime example of this mode of advancement. He was both a member of a hetaireia and then patron of one just before the assassination of his predecessor Michael III (Beck 1965: 4-18). His abilities and looks played a part in his rise. A hetaireia from the beginning of the ninth century supported by Bardanes Tourkos that contained the future emperors Leo V (813-820) and Michael II (820829) provides still another example (Beck 1965: 18-22). Beck 1965: 28, perhaps goes too far when he emphasizes the extra-constitutional nature of hetaireiai, as members of the hetaireia and the hetraireiarch had places in imperial ceremonial (Oikonomidès 1972: 35, 63). That said, though, the roles of the members of a hetaireia were ad hoc, and the tastes of the leader/sponsor determined membership. Beck 1965: 26-27, also speaks of a possible hetaireia associated with Basil II that included members of the Komnenos family (Nikephoros Bryennios, Historia 1.2.1-2: 'E $\pi \varepsilon \dot{~} \delta \dot{\varepsilon} \delta i \eta \lambda \lambda \alpha \xi \alpha \dot{\alpha} \tau \eta$

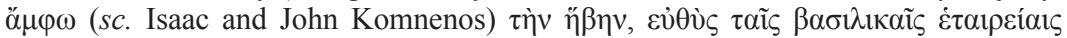

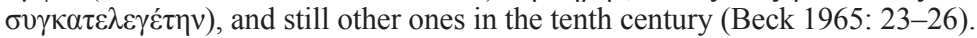

156 Hussey 1967: 183; Turner 1990; Morris 1995.

157 For connections between monks and men in the world, see Turner 1990: esp. 34, 55, $106,119,231,234-241$. Morris 1995 is dedicated to interactions between monks and laymen and is relevant frequently on this point. More specifically, Morris 1995: 76-80, delineates ways in which monks frequently were indistinguishable from their secular brothers in terms of education and family background. She also discusses a number of interactions between the secular and sacred milieux (Morris 1995: 84-87). Morris 1995: 106, sums up a dynamic that she documents repeatedly throughout her study, referring here to relations of spiritual fatherhood: "From members of the Byzantine administrative "middle management" as far up as the imperial families themselves, the clients [of the monks acting as spiritual fathers] represented a cross-section of the Byzantine ruling class. They consulted their spiritual fathers either in person or by letter, and it is very likely that they were well aware of others who also sought guidance from the same source'. Of interest too is the title of Symeon's fourth hymn, which is called 'A teaching to the monks who have recently left the world and to those who

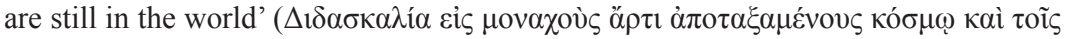
$\dot{\varepsilon} \vee \kappa o ́ \sigma \mu()$. He addresses monks and those who, not living in a monastery, desired guidance. Relevant too are the comments of Rapp 2016: 168-169, 192-193, 210, on relations between monks and laymen and the connections that Symeon maintained.

158 Niketas Stethatos, Vita Symeonis 100.

159 Turner 1990: 11.

160 Symeon the New Theologian, Catecheses 22.22-27; McGuckin 1996: 19-20.

\section{References}

Aerts, W.J. (1990), Michaelis Pselli Historia Syntomos. Berlin/New York. Angold, M. (1997), The Byzantine Empire 1025-1204: A Political History. New York. Arbagi, M. (1975), 'The celibacy of Basil II', Byzantine Studies 2.1: 41-45.

Arranz, M. (1993), I Penitenziali Bizantini: Il Protokanonarion o Kanonarion Primitivo di Giovanni Monaco e Diacono e il Deuterokanonarion o 'Secondo Kanonarion' di Basilio Monaco. Rome.

Beck, H.-G. (1965), Byzantinisches Gefolgschaftswesen. Munich.

Bekker, I. (1838), Theophanes Continuatus: Ioannes Cameniata, Symeon Magister, Georgius Monachus. Bonn.

Bourgain, P., Landes, R., and Pon, G., eds. (1999), Ademarus Cabannensis (Adémar de Chabannes): Opera Omnia. Turnhout. 


\section{MARK MASTERSON}

Brokkaar, W.G. (1972), 'Basil Lacapenus. Byzantium in the 10th century', in W.F. Bakker et al., eds., Studia Byzantina et Neohellenica Neerlandica, Leiden: 199-234.

Burgmann, L. (1983), Ecloga: Das Gesetzbuch Leons III und Constantine V. Frankfurt am Main.

Crostini, B. (1996), 'The emperor Basil II's cultural life', Byz 64: 55-80.

Darrouzès, J. (1960), Épistoliers byzantins du Xe siècle. Paris.

Darrouzès, J. (1966), Traités théologiques et éthiques [par] Syméon le Nouveau Théologien, vol. 1. Paris.

Darrouzès, J. (1967), Traités théologiques et éthiques [par] Syméon le Nouveau Théologien, vol. 2. Paris.

Darrouzès, J., and Neyrand, L. (1996), Syméon le Nouveau Théologien: Chapitres théologiques, gnostiques, et pratiques. Paris.

Delehaye, H., and Peeters, P. (1925). Acta Sanctorum: Novembris, Tomus IV, Quo Dies nonus et decimus Continentur. Brussels.

Featherstone, J.M. (1998), 'The Logothete Chronicle in Vat. gr. 163', Orientalia Christiana Periodica 64: 419-434.

Featherstone, J.M., and Signes-Codoñer, J. (2015), Chronographiae Quae Theophanis Continuati Nomine Fertur Libri I-IV (Nuper Repertis Schedis Caroli de Boor Adiuvantibus). Berlin/New York.

Garland, L. (1999a), 'Basil II as humorist', Byz 69.2: 321-343.

Garland, L. (1999b), Byzantine Empresses: Women and Power in Byzantium, AD 527-1204. New York.

Golitzin, A. (1998), Symeon: On the Mystical Life: The Ethical Discourses, vol. 3. Crestwood, NY.

Hase, K.B. (1828), Leonis Diaconi Caloënsis: Historiae Libri Decem. Bonn.

Hausherr, I., and Horn, P.G. (1928), Un grand mystique byzantin: Vie de Syméon le Nouveau Théologien (949-1022) par Nicétas Stéthatos. Rome.

Holmes, C. (2003), 'Political elites in the reign of Basil II', in P. Magdalino, ed., Byzantium in the Year 1000, Leiden: 35-69.

Holmes, C. (2005), Basil II and the Governance of Empire (976-1025). Oxford.

Holmes, C. (2006), 'Constantinople in the reign of Basil II', in E.M. Jeffreys, ed., Byzantine Style, Religion and Civilization: In Honour of Sir Steven Runciman, Cambridge: 326-339.

Hussey, J.M. (1967), 'Byzantine monasticism', Cambridge Medieval History, vol. 4.2, Cambridge: $161-184$.

Istrin, V.M. (1920), Knigy Vremen'nyia I Obraznyia Geōrgiīa Mnikha : Khronika Georgîia Amartola v Drevnem Slavianorusskom Perevodie: Tekst, Izstiedovanīe I Slovar'. Petrograd.

Joannou, P.-P. (1963), Discipline générale antique (IIe-IXe s.). Vol. II: Les canons des pères grecs. Rome.

Kambylis, A. (1976), Symeon Neos Theologos: Hymnen. Berlin/New York.

Krivochéine, B., and Paramelle, J. (1963), Syméon le Nouveau Théologien: Catéchèses, vol. 1. Paris.

Krivochéine, B., and Paramelle, J. (1964), Syméon le Nouveau Théologien: Catéchèses, vol. 2. Paris.

Krueger, D. (2006), 'Homoerotic spectacle and the monastic body in Symeon the New Theologian', in V. Burrus and C. Keller, eds., Toward a Theology of Eros: Transfiguring Passion at the Limits of Discipline, New York: 99-118.

Laiou, A.E. (1992), Mariage, amour et parenté à Byzance aux XIe-XIIIe siècles. Paris. 
Macrides, R. (1992), 'Dynastic marriages and political kinship', in J. Shepard and S. Franklin, eds., Byzantine Diplomacy, Aldershot: 263-280.

Magdalino, P. (2003), 'The year 1000 in Byzantium', in P. Magdalino, ed., Byzantium in the Year 1000, Leiden: 233-270.

Masterson, M. (2014), Man to Man: Desire, Homosociality and Authority in Late-Roman Manhood. Columbus, $\mathrm{OH}$.

McGuckin, J. (1996), 'Symeon the New Theologian and Byzantine monasticism', in A. Bryer and M. Cunningham, eds., Mount Athos and Byzantine Monasticism, Aldershot: $17-35$.

McGuckin, J. (2005), 'Symeon the New Theologian's hymns of divine Eros: A neglected masterpiece of the Christian mystical tradition', Spiritus 5.2: 182-202, 225.

Messis, C. (2006), La construction sociale, les " réalités " rhétoriques et les représentations de L'identité masculine à Byzance. Doctoral Dissertation. Centre d'études byzantines, néo-helléniques et sud-est européennes.

Messis, C. (2014), Les eunuques à Byzance, entre réalité et imaginaire. Paris.

Morris, R. (1995), Monks and Laymen in Byzantium, 843-1118. Cambridge.

Morris, S. (2016), 'When Brothers Dwell in Unity': Byzantine Christianity and Homosexuality. Jeferrson, NC.

Mullett, M. (1988), 'Byzantium: A friendly society?', Past and Present 118: 3-24.

Oikonomidès, N. (1972), Les listes de préséance byzantines des IXe et Xe siècles. Paris.

Ostrogorsky, G. (1968), History of the Byzantine State, trans. J. Hussey, 2nd ed. Oxford.

Pitsakis, K. (2000), 'Législation et stratégies matrimoniales: Parenté et empêchements de mariage dans le droit byzantin', L'Homme 154/155: 677-696.

Pitsakis, K. (2008), 'L'homoérotisme dans la culture byzantine: le cadre normatif et ses reflets littéraires', in P. Odorico and N. Pasero, eds., Corrispondenza d'Amorosi Sensi: L'Omoerotismo nella Letteratura Medievale, Alessandria: 1-29.

Rapp, C. (2016), Brother-Making in Late Antiquity and Byzantium: Monks, Laymen and Christian Ritual. New York.

Renauld, E. (1967), Michel Psellos: Chronographie ou Histoire d'un siècle de Byzance (976-1077). Paris.

Rhalle, G.A., and Potle, M. (1854), Syntagma tōn Theōn kai Hierōn Kanonōn tōn te Hagiōn kai Paneuphēmōn Apostolōn, kai tōn Hierōn Oikoumenikōn kai Topikōn Synodōn, kai tōn kata Meros Hagiōn Paterōn, vol. 4. Athens.

Schreiner, P. (1991), 'Réflexions sur la famille impériale à Byzance (VIIIe-Xe siècles)', Byz 61: 181-193.

Sedgwick, E.K. (1990), Epistemology of the Closet. Berkeley.

Sewter, E. (1979), Fourteen Byzantine Rulers: The Chronographia of Michael Psellus, rev. ed. Harmondsworth.

Shepard, J. (2003), 'Marriages towards the millenium', in P. Magdalino, ed., Byzantium in the Year 1000, Leiden: 1-33.

Sifonas, C.S. (1994), 'Basile II et l'aristocratie byzantine', Byz 64: 118-133.

Simon, D., and Troianos, S.N. (1977), 'Eklogadion und Ecloga privata aucta', Fontes Minores II: 45-86.

Stephenson, P. (2003), The Legend of Basil the Bulgar-slayer. Cambridge.

Smythe, D.C. (1999), 'In denial: Same-sex desire in Byzantium', in L. James, ed., Desire and Denial in Byzantium, Aldershot: 139-148.

Svoronos, N. (1994), Les Novelles des empereurs Macédoniens concernant la terre et les stratiotes. Athens. 


\section{MARK MASTERSON}

Talbot, A.-M. (1996), Holy Women of Byzantium: Ten Saints' Lives in English Translation. Washington, DC.

Talbot, A.-M., and Sullivan, D.F. (2005), The History of Leo the Deacon: Byzantine Military Expansion in the Tenth Century. Washington, DC.

Thurn, J. (1973), Ioannis Scylitzae: Synopsis Historiarum. Berlin.

Tougher, S. (2008), The Eunuch in Byzantine History and Society. New York.

Tougher, S. (2013), 'Imperial families: The case of the Macedonians (867-1056)', in L. Brubaker and S. Tougher, eds., Approaches to the Byzantine Family, Burlington, VT: 303-326.

Treadgold, W. (1997), A History of the Byzantine State and Society. Stanford.

Treadgold, W. (2013), The Middle Byzantine Historians. New York.

Troianos, S. (1989), 'Kirchliche und weltliche Rechtsquellen zur Homosexualität in Byzanz', JÖB 39: 29-48.

Turner, H.J.M. (1990), St. Symeon: The New Theologian and Spiritual Fatherhood. Leiden.

Van Opstall, E.M. (2008), Jean Géomètre: Poèmes en hexamètres et en distiques élégiaques. Leiden.

Vinson, M.P. (1985), The Correspondence of Leo, Metropolitan of Synada and Syncellus. Washington, DC.

Wahlgren, S. (2006), Symeonis Magistri et Logothetae Chronicon. Berlin.

Wolff, R.L. (1978), 'How the news was brought from Byzantium to Angoulême; or, the pursuit of the hare in an ox cart', BMGS 4: 139-189.

Wortley, J. (2010), John Skylitzes: A Synopsis of Byzantine History, 811-1057. New York.

Zepos, I.D., and Zepos, P.I. (1931), Jus Graecoromanum II. Leges Imperatorum Isaurorum et Macedonum. Athens. 